\title{
Elucidating the origins of a range of diverse flexible responses in crystalline coordination polymers
}

\author{
Mateja Pisačić, ${ }^{\mathrm{a}}$ Ivana Biljan, ${ }^{\mathrm{a}}$ Ivan Kodrin, ${ }^{\mathrm{a}}$ Nina Popov, ${ }^{\mathrm{b}}$ Željka Soldina and Marijana Đakovića* \\ ${ }^{a}$ Department of Chemistry, Faculty of Science, University of Zagreb, Zagreb, Croatia \\ ${ }^{b}$ Ruđer Bošković Institute, Bijenička c. 54, Zagreb, Croatia
}

Supplementary information 
Table of Contents

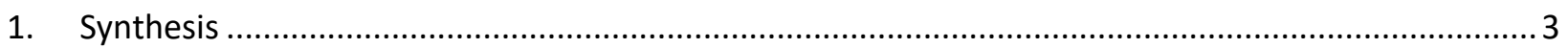

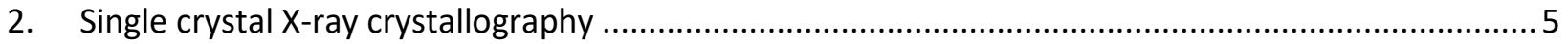

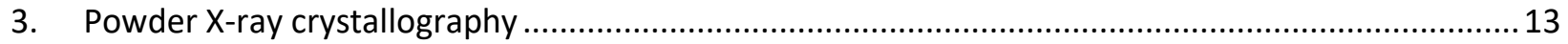

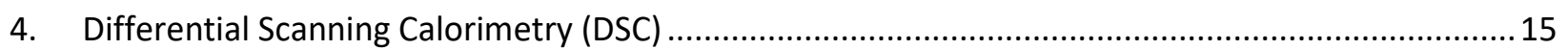

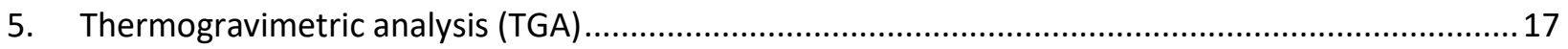

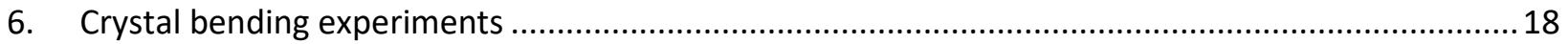

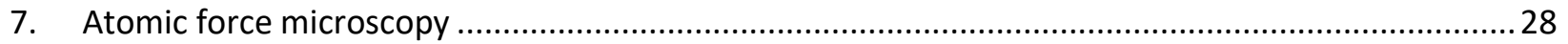

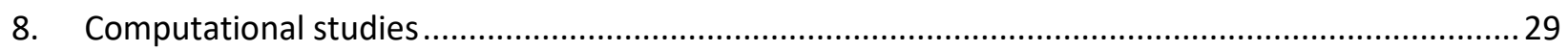

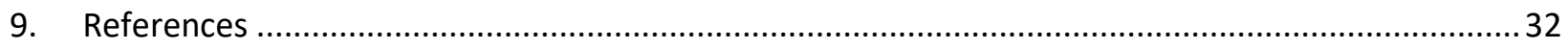




\section{Synthesis}

All metal salts, precursors and solvents were purchased from commercial suppliers and used without further purification.

General procedure for preparation 4-6. Solutions prepared by dissolving cadmium(II) salt (1 eq.) in water $(5 \mathrm{~mL})$ and 3-iodopyridine (2 eq.) in ethanol $(5 \mathrm{~mL})$ were mixed together and stirred for 30 minutes. White precipitate was filtered off and washed with small amounts of cold water.

$\left[\mathrm{CdCl}_{2}(3-\mathrm{Ipy})_{2}\right]_{n}, 4$. Used: $\mathrm{CdCl}_{2} \cdot \mathrm{H}_{2} \mathrm{O}(112 \mathrm{mg}, \sim 0.56 \mathrm{mmol})$ and 3-Ipy (213 $\left.\mathrm{mg}, \sim 1.04 \mathrm{mmol}\right)$. Microanalysis. Calcd. for $\mathrm{C}_{10} \mathrm{H}_{8} \mathrm{Cl}_{2} \mathrm{I}_{2} \mathrm{~N}_{2} \mathrm{Cd}\left(\mathrm{Mr}_{\mathrm{r}}=593.28\right)$ : C, 20.24\%; $\mathrm{H}, 1.36 \% ; \mathrm{N}, 4.72 \%$. Found: $\mathrm{C}, 21,02 \% ; \mathrm{H}, 1.42 \%$; N, 4.38\%. The powder diffraction pattern (bulk sample) was consistent with the pattern calculated from the single-crystal data (Figure S4).

[CdBr 2 (3-Ipy) $]_{n}$, 5. Used: $\mathrm{CdBr}_{2} \cdot 4 \mathrm{H}_{2} \mathrm{O}(171 \mathrm{mg}, \sim 0.49 \mathrm{mmol})$ and 3-Ipy $(216 \mathrm{mg}, \sim 1.06$ mmol). Microanalysis. Calcd. for $\mathrm{C}_{10} \mathrm{H}_{8} \mathrm{Br}_{2} \mathrm{I}_{2} \mathrm{~N}_{2} \mathrm{Cd}\left(\mathrm{Mr}_{\mathrm{r}}=682.18\right): \mathrm{C}, 17.60 \% ; \mathrm{H}, 1.18 \% ; \mathrm{N}$, 4.11\%. Found: C, 17,54\%; H, 1.20\%; N, 4.06\%. The powder diffraction pattern (bulk sample) was consistent with the pattern calculated from the single-crystal data (Figure S5).

[Cdl 2 (3-Ipy) $]_{n}$, 6. Used: $\mathrm{Cdl}_{2}(189 \mathrm{mg}, \sim 0.52 \mathrm{mmol})$ and 3-Ipy (208 $\left.\mathrm{mg}, \sim 1.02 \mathrm{mmol}\right)$. Microanalysis. Calcd. for $\mathrm{C}_{10} \mathrm{H}_{8}{ }_{4} \mathrm{~N}_{2} \mathrm{Cd}\left(\mathrm{Mr}_{\mathrm{r}}=776.18\right)$ : $\mathrm{C}, 15.47 \% ; \mathrm{H}, 1.04 \% ; \mathrm{N}, 3.61 \%$. Found: C, $15.43 \%$; H, $1.06 \%$; N, 3.55\%. The powder diffraction pattern (bulk sample) was consistent with the pattern calculated from the single-crystal data (Figure S6). 


\section{Growing Crystals}

\section{General procedure for growing crystals by layering technique}

A solution prepared by dissolving cadmium(II) salt ( $\mathrm{CdX}_{2}, 1$ eq.) in water was added to a test tube and carefully layered with $1 \mathrm{~mL}$ of ethanol. A solution prepared by dissolving a ligand (2 eq.) in ethanol was then added to ethanol layer. The resulting test tubes were sealed using parafilm and left undisturbed. After a week a few holes were punctured in the parafilm to allow slow evaporation. White needle-like crystals were harvested after a few weeks.

$\left[\mathrm{CdBr}_{2}(3-\mathrm{Clpy})_{2}\right]_{n},(\mathbf{1}, \mathrm{IPAYIH})$. Used: $\mathrm{CdBr}_{2}$ aqueous solution $\left(1 \mathrm{~mL}, 0.048 \mathrm{~mol} \mathrm{dm}^{-3}\right)$, 3-Clpy ethanol solution $\left(2 \mathrm{~mL}, 0.050 \mathrm{~mol} \mathrm{dm}^{-3}\right)$.

[Cdl 2 (3-Clpy) $]_{n},\left(2\right.$, IPAYON). Used: $\mathrm{Cdl}_{2}$ aqueous solution $\left(1 \mathrm{~mL}, 0.051 \mathrm{~mol} \mathrm{dm}^{-3}\right), 3-\mathrm{Clpy}$ ethanol solution $\left(2 \mathrm{~mL}, 0.049 \mathrm{~mol} \mathrm{dm}^{-3}\right)$.

$\left[\mathrm{Cdl}_{2}(3-\mathrm{Brpy})_{2}\right]_{n},\left(3\right.$, IPAZEE). Used: $\mathrm{Cdl}_{2}$ aqueous solution $\left(1 \mathrm{~mL}, 0.053 \mathrm{~mol} \mathrm{dm}^{-3}\right), 3-\mathrm{Brpy}$ ethanol solution ( $\left.2 \mathrm{~mL}, 0.049 \mathrm{~mol} \mathrm{dm}^{-3}\right)$.

$\left[\mathrm{CdCl}_{2}(3-\mathrm{Ipy})_{2}\right]_{n},(4)$. Used: $\mathrm{CdCl}_{2}$ aqueous solution $\left(1 \mathrm{~mL}, 0.049 \mathrm{~mol} \mathrm{dm}{ }^{-3}\right.$ ), 3-Ipy ethanol solution ( $\left.2 \mathrm{~mL}, 0.051 \mathrm{~mol} \mathrm{dm}^{-3}\right)$.

$\left[\mathrm{CdBr}_{2}(3-\mathrm{Ipy})_{2}\right]_{n},(5)$. Used: $\mathrm{CdBr}_{2}$ aqueous solution $\left(1 \mathrm{~mL}, 0.050 \mathrm{~mol} \mathrm{dm}^{-3}\right.$ ), 3-Ipy ethanol solution ( $2 \mathrm{~mL}, 0.054 \mathrm{~mol} \mathrm{dm}^{-3}$ ).

$\left[\mathrm{Cdl}_{2}(3-\mathrm{Ipy})_{2}\right]_{n},(6)$. Used: $\mathrm{Cdl}_{2}$ aqueous solution $\left(1 \mathrm{~mL}, 0.052 \mathrm{~mol} \mathrm{dm}^{-3}\right)$, 3-Ipy ethanol solution $\left(2 \mathrm{~mL}, 0.048 \mathrm{~mol} \mathrm{dm}^{-3}\right)$. 


\section{Single crystal X-ray crystallography}

Crystal structure determination. Single crystals (4-6) were mounted on a glass fiber using two component glue. Data collections were carried out on an Oxford Diffraction Xcalibur four-circle kappa geometry single-crystal diffractometer with Sapphire 3 CCD detector, using a graphite monochromated $\operatorname{MoK} \alpha(\lambda=0.71073 \AA)$ radiation, and applying the CrysAlisPro Software system ${ }^{1}$ at $296(2)$ K. Data reduction, including absorption correction, was done by CrysAlisPro program. The structures were solved by SHELXT program. ${ }^{2}$ The coordinates and the anisotropic thermal parameters for all non-hydrogen atoms were refined by full-matrix least-squares methods based on $F^{2}$ using the SHELXL program. ${ }^{3}$ The hydrogen atoms were generated geometrically using the riding model with the isotropic factor set at $1.5 U_{\text {eq. }}$

Graphical work has been performed by Mercury 4.3.1. ${ }^{4}$ The thermal ellipsoids were drawn at the $50 \%$ probability level. General and crystal data with the summary of intensity data collection and structure refinement for compounds 4-6 are given in Table S1 (ESI).

CCDC 1991011-1991013 contain the supplementary crystallographic data for this paper.

Evaluation of the structural changes in plastically deformed crystals. Crystals of $\mathbf{2}$ were mounted on a glas fiber in the bent form, and data collections were performed on an XtaLAB Synergy-S Dualflex diffractometer with PhotonJet (Mo) microfocus X-ray source and HyPix-6000HE hybrid photon counting (HPC) X-ray area detector, applying CrysAlisPro Software system, at $170(2) \mathrm{K}$. 
Table S1. Crystal data and details of the structure determination for 4-6.

\begin{tabular}{|c|c|c|c|}
\hline Compound & 4 & 5 & 6 \\
\hline Formula & $\mathrm{C}_{10} \mathrm{H}_{8} \mathrm{CdCl}_{2} \mathrm{I}_{2} \mathrm{~N}_{2}$ & $\mathrm{C}_{10} \mathrm{H}_{8} \mathrm{CdBr}_{2} \mathrm{I}_{2} \mathrm{~N}_{2}$ & $\mathrm{C}_{10} \mathrm{H}_{8} \mathrm{Cdl}_{4} \mathrm{~N}_{2}$ \\
\hline$M_{r}$ & 593.28 & 682.20 & 776.18 \\
\hline Colour and habit & $\begin{array}{l}\text { colourless } \\
\text { needle }\end{array}$ & $\begin{array}{l}\text { colourless } \\
\text { needle }\end{array}$ & $\begin{array}{l}\text { colourless } \\
\text { needle }\end{array}$ \\
\hline Crystal system, space group & $\begin{array}{c}\text { Monoclinic, } \\
C 2 / c\end{array}$ & $\begin{array}{c}\text { Triclinic, } \\
P \overline{1}\end{array}$ & $\begin{array}{l}\text { Monoclinic, } \\
P 2_{1} / c\end{array}$ \\
\hline Crystal dimensions $\left(\mathrm{mm}^{3}\right)$ & $0.31 \times 0.06 \times 0.03$ & $0.40 \times 0.10 \times 0.06$ & $0.20 \times 0.06 \times 0.05$ \\
\hline$a(\AA)$ & $17.5567(5)$ & $4.0326(2)$ & $4.20870(10)$ \\
\hline$b(\AA)$ & $3.95080(10)$ & $8.7671(4)$ & $14.9629(4)$ \\
\hline$c(\AA)$ & $20.4768(5)$ & $10.5541(4)$ & $13.0234(4)$ \\
\hline$\alpha\left(^{\circ}\right)$ & 90 & $93.642(4)$ & 90 \\
\hline$\beta\left(^{\circ}\right)$ & $96.843(2)$ & $90.927(4)$ & $90.728(3)$ \\
\hline$\gamma\left({ }^{\circ}\right)$ & 90 & $94.739(4)$ & 90 \\
\hline$V\left(\AA^{3}\right)$ & $1410.21(6)$ & $371.02(3)$ & $820.07(4)$ \\
\hline$Z$ & 4 & 1 & 2 \\
\hline$D_{\text {calc }}\left(\mathrm{g} \mathrm{cm}^{-3}\right)$ & 2.794 & 3.035 & 3.143 \\
\hline$\mu\left(\mathrm{mm}^{-1}\right)$ & 6.284 & 10.997 & 8.843 \\
\hline$F(000)$ & 1080 & 306 & 684 \\
\hline $\begin{array}{l}\theta \text { range for data collection } \\
\left({ }^{\circ}\right)\end{array}$ & $4.40-29.00$ & $4.39-28.00$ & $4.82-30.55$ \\
\hline$h, k$, I range & $-23: 23,-5: 4,-27: 27$ & $-5: 5,-11: 11,-13: 13$ & $-5: 4,-16: 17,-15: 17$ \\
\hline Scan type & $\omega$ & $\omega$ & $\omega$ \\
\hline No. measured reflections & 5796 & 9687 & 7944 \\
\hline $\begin{array}{l}\text { No. independent reflections } \\
\left(R_{\text {int }}\right)\end{array}$ & $1870(0.0318)$ & $1788(0.0211)$ & $1980(0.0304)$ \\
\hline $\begin{array}{l}\text { No. observed reflections, } \\
I \geq 2 \sigma(I)\end{array}$ & 1504 & 1591 & 1627 \\
\hline No. refined parameters & 78 & 80 & 80 \\
\hline$R, \mathrm{w} R[I \geq 2 \sigma(I)]$ & $0.0264,0.0402$ & $0.0230,0.0528$ & $0.0239,0.0425$ \\
\hline$R, \mathrm{w} R$ [all data] & $0.0450,0.0476$ & $0.0281,0.0549$ & $0.0349,0.0454$ \\
\hline Goodness of fit on $F^{2}, S$ & 0.949 & 1.063 & 1.007 \\
\hline $\begin{array}{l}\text { Max., min. electron density } \\
\left(\mathrm{e} \AA^{-3}\right)\end{array}$ & $0.516,-0.678$ & $1.008,-0.633$ & $0.565,-0.511$ \\
\hline CCDC number & 1991011 & 1991012 & 1991013 \\
\hline
\end{tabular}


Table S2. Selected bond distances ( $\AA$ ) and angles ( $\left(^{\circ}\right)$ for 4-6.

\begin{tabular}{cccc}
\hline & $\mathbf{4}$ & 5 & 6 \\
\hline $\mathrm{Cd} 1-\mathrm{N} 1$ & $2.350(3)$ & $2.381(3)$ & $2.395(3)$ \\
$\mathrm{Cd} 1-\mathrm{X} 1$ & $2.6620(9)$ & $2.8151(4)$ & $2.9459(3)$ \\
$\mathrm{Cd} 1-\mathrm{X} 1^{i}$ & $2.6734(9)$ & $2.7631(4)$ & $3.0319(3)$ \\
$\mathrm{N} 1-\mathrm{Cd} 1-\mathrm{X} 1$ & $91.87(8)$ & $89.93(8)$ & $89.88(7)$ \\
$\mathrm{N} 1-\mathrm{Cd} 1-\mathrm{X} 1^{i}$ & $89.62(8)$ & $90.48(7)$ & $90.12(7)$ \\
$\mathrm{N} 1-\mathrm{Cd} 1-\mathrm{X} 1^{i i}$ & $90.38(8)$ & $89.52(7)$ & $90.04(7)$ \\
$\mathrm{N} 1-\mathrm{Cd} 1-\mathrm{X} 1^{i i i}$ & $88.13(8)$ & $90.07(7)$ & $89.96(7)$ \\
$\mathrm{X} 1-\mathrm{Cd} 1-\mathrm{X} 1^{i}$ & $95.55(3)$ & $92.587(12)$ & $90.506(7)$ \\
$\mathrm{X} 1-\mathrm{Cd} 1-\mathrm{X} 1^{i i}$ & $84.68(4)$ & $87.413(12)$ & $89.494(7)$ \\
\hline
\end{tabular}

Symmetry codes: (i): $\mathrm{x}, \mathrm{y}+1, \mathrm{z} ;($ ii): $-\mathrm{x}+1, \mathrm{y},-\mathrm{z}+1 / 2 ;$ (iii): $-\mathrm{x}+1, \mathrm{y}+1,-\mathrm{z}+1 / 2 ; \mathrm{X}=\mathrm{Cl}$ (4)

(i): $x+1, y, z ;($ ii): $-x,-y+1,-z+1$; (iii): $-x+1,-y+1,-z+1 ; x=\operatorname{Br}(5)$

(i): $-\mathrm{x},-\mathrm{y}+1,-\mathrm{z}+1 ;($ ii): $\mathrm{x}+1, \mathrm{y}, \mathrm{z} ;($ iii): $-\mathrm{x}+1,-\mathrm{y}+1,-\mathrm{z}+1 ; \mathrm{X}=\mathrm{I}(6)$ 
Table S3. Details on hydrogen bond geometry $\left(\AA{ }^{\circ}{ }^{\circ}\right)$ for 1-6.

\begin{tabular}{|c|c|c|c|c|}
\hline $\mathrm{D}-\mathrm{H} \cdots \mathrm{A}$ & $d(\mathrm{H} \cdots \mathrm{A}) / \AA$ & $d(\mathrm{D} \cdots \mathrm{A}) / \AA$ & $\angle(\mathrm{D}-\mathrm{H} \cdots \mathrm{A}) /^{\circ}$ & $R_{\mathrm{HX}}^{a}$ \\
\hline \multicolumn{5}{|l|}{1 (IPAYIH) } \\
\hline $\mathrm{C} 4-\mathrm{H} 3 \cdots \mathrm{Br}^{i}$ & 2.96 & $3.745(7)$ & 138.0 & 0.97 \\
\hline \multicolumn{5}{|l|}{2 (IPAYON) } \\
\hline $\mathrm{C} 4-\mathrm{H} 3 \cdots \cdot 1^{i}$ & 3.19 & $3.997(6)$ & 141.0 & 1.01 \\
\hline \multicolumn{5}{|l|}{3 (IPAZEE) } \\
\hline $\mathrm{C} 4-\mathrm{H} 3 \cdots \cdot 1^{i}$ & 3.19 & $3.979(5)$ & 139.0 & 1.01 \\
\hline \multicolumn{5}{|l|}{4} \\
\hline $\mathrm{C} 4-\mathrm{H} 9 \cdots \mathrm{Cl} 1^{i i}$ & 3.03 & $3.702(4)$ & 130.2 & 1.03 \\
\hline $\mathrm{C} 3-\mathrm{H} 8 \cdots \cdot 1^{i i i}$ & 3.21 & $3.978(4)$ & 141.0 & 1.02 \\
\hline \multicolumn{5}{|l|}{5} \\
\hline $\mathrm{C} 3-\mathrm{H} 3 \cdots \mid 1^{i v}$ & 3.27 & $4.015(4)$ & 138.6 & 1.04 \\
\hline $\mathrm{C} 4-\mathrm{H} 4 \cdots \mathrm{Br} 1^{v}$ & 3.23 & $4.134(4)$ & 163.0 & 1.06 \\
\hline \multicolumn{5}{|l|}{6} \\
\hline $\mathrm{C} 1-\mathrm{H} 1 \cdots \mid 1^{v i}$ & 3.30 & $4.023(5)$ & 136.6 & 1.04 \\
\hline
\end{tabular}

a The normalized distance, $R$, defined according to Lommerse et al. ${ }^{5} R_{\mathrm{HX}}=d(\mathrm{H} \cdots \mathrm{X}) /\left(r_{\mathrm{H}}+r_{\mathrm{X}}\right)$, where $r_{\mathrm{H}}$ and $r_{\mathrm{x}}$ are the Bondi van der Waals radii of the respective hydrogen-bond donor and acceptor atoms $(\mathrm{H} 1.20, \mathrm{Cl} 1.75, \mathrm{Br} 1.86$, or I $1.98 \AA$ ) in the $\mathrm{C}-\mathrm{H} \cdot \cdots \mathrm{X}$ hydrogen bond.

Symmetry codes (i): $-\mathrm{x}-1, \mathrm{y}+1 / 2,-\mathrm{z}-1 / 2 ;(i i):-\mathrm{x}+1 / 2, \mathrm{y}+1 / 2,-\mathrm{z}+1 / 2$ (iii): $-\mathrm{x}+1 / 2,-\mathrm{y}+1 / 2,-\mathrm{z}+1 ;($ iv): $\mathrm{x}$, $-y+1 / 2, z-1 / 2 ;(v):-x,-y+2,-z+1 ;(v i):-x+1,-y+2,-z$.

Table S4. Details on halogen bond geometry $\left.(\AA)^{\circ}\right)$ for 1-6.

\begin{tabular}{|c|c|c|c|}
\hline$D-X 1 \cdots \times 2$ & $d(\mathrm{X} 1 \cdots \mathrm{X} 2) / \AA$ & $\angle(\mathrm{D}-\mathrm{X} \cdot \mathrm{A}) /^{\circ}$ & $R_{\times 1 \times 2^{a}}^{a}$ \\
\hline \multicolumn{4}{|l|}{1 (IPAYIH) } \\
\hline $\begin{array}{l}\mathrm{C} 2-\mathrm{Cl} 1 \cdots \mathrm{Br} 1^{i} \\
2 \text { (IPAYON) }\end{array}$ & $3.651(2)$ & $167.0(3)$ & 1.011 \\
\hline $\begin{array}{l}\mathrm{C} 2-\mathrm{Cl} 1 \cdots \mid 1^{i} \\
3 \text { (IPAZEE) }\end{array}$ & $3.802(2)$ & $171.10(16)$ & 1.019 \\
\hline $4^{\mathrm{C} 2-\mathrm{Br} 1 \cdots \mid 1^{i}}$ & $3.7566(10)$ & 169.99(11) & 0.978 \\
\hline $\mathrm{C} 2-\mathrm{I} \cdots \mathrm{Cl} 3^{i i}$ & $3.4388(9)$ & $178.55(10)$ & 0.922 \\
\hline $6 \quad \mathrm{C} 2-\mid 1 \cdots \mathrm{Br} 1^{i i i}$ & $3.5385(4)$ & 173.21(9) & 0.921 \\
\hline$C 2-12 \cdots 11^{i v}$ & $3.7926(4)$ & $168.09(11)$ & 0.958 \\
\hline
\end{tabular}

a The normalized distance, $R$, defined according to Lommerse et $\left.a\right|^{5} R \times 1 \times 2=d(\mathrm{X} 1 \cdots \times 2) /(r 1+r 2)$, where $r 1$ and $r 2$ are the Bondi van der Waals radii of the respective halogen atoms $(\mathrm{Cl} 1.75, \mathrm{Br} 1.86$, or I $1.98 \AA$ ) in the $\mathrm{D}-\mathrm{X} 1 \cdots \mathrm{X} 2$ halogen bond.

Symmetry codes: (i): $x+1,-y+1 / 2, z+1 / 2 ;(i i): x,-y, z+1 / 2 ;(i i i): x+1, y, z+1 ;(i v):-x+1, y-1 / 2,-z+3 / 2$. 

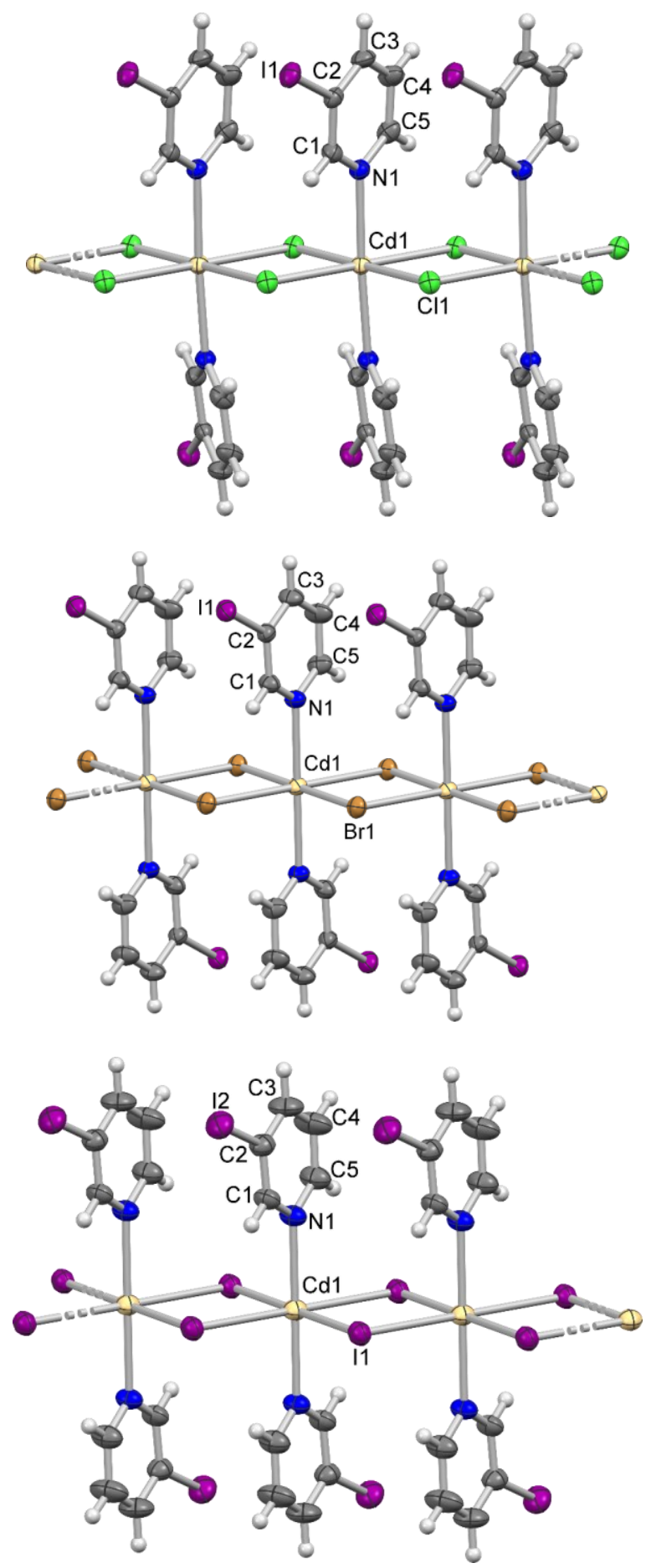

Figure S1. ORTEP-style plot of $\left[\mathrm{CdCl}_{2}(3-\mid \mathrm{py})_{2}\right]_{\mathrm{n}}(4),\left[\mathrm{CdBr}_{2}(3-\mathrm{Ipy})_{2}\right]_{\mathrm{n}}(5)$ and $\left[\mathrm{Cdl}_{2}(3-\mathrm{Ipy})_{2}\right]_{\mathrm{n}}(6)$, top, middle and bottom, respectively, with partial labelling scheme. Thermal ellipsoids are drawn at $50 \%$ probability level at $296(2) \mathrm{K}$. 


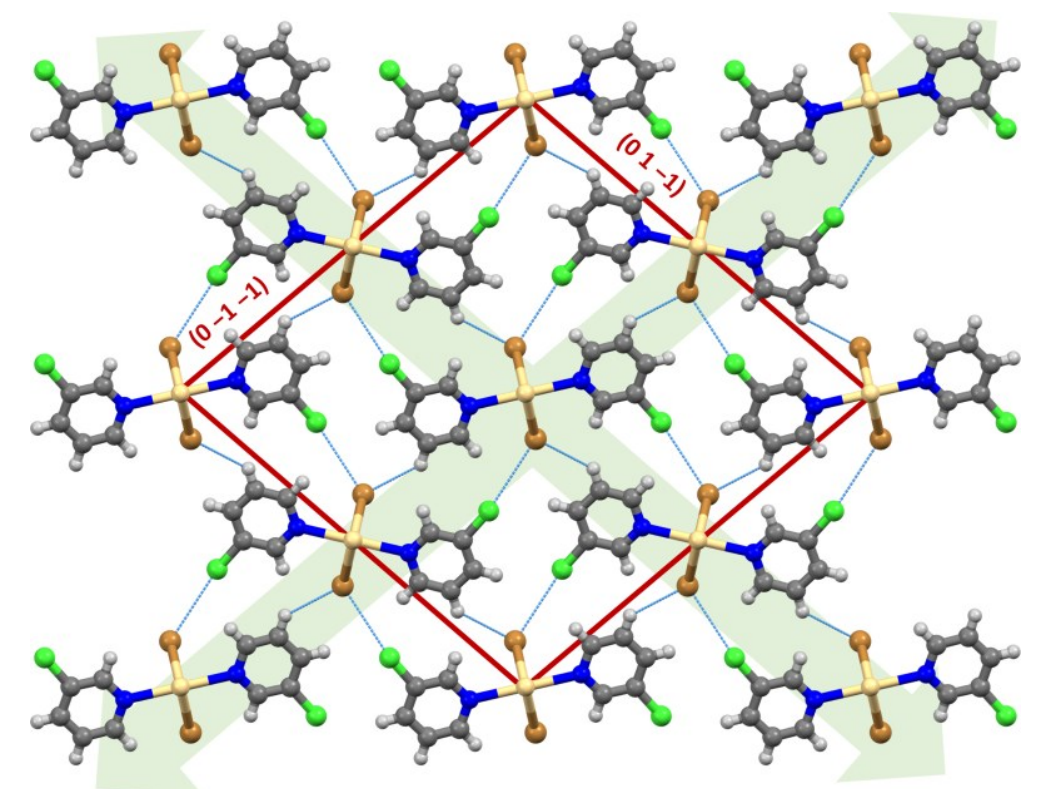

$\left[\mathrm{CdBr}_{2}(3-\mathrm{Clpy})_{2}\right]_{n}(\mathbf{1})$

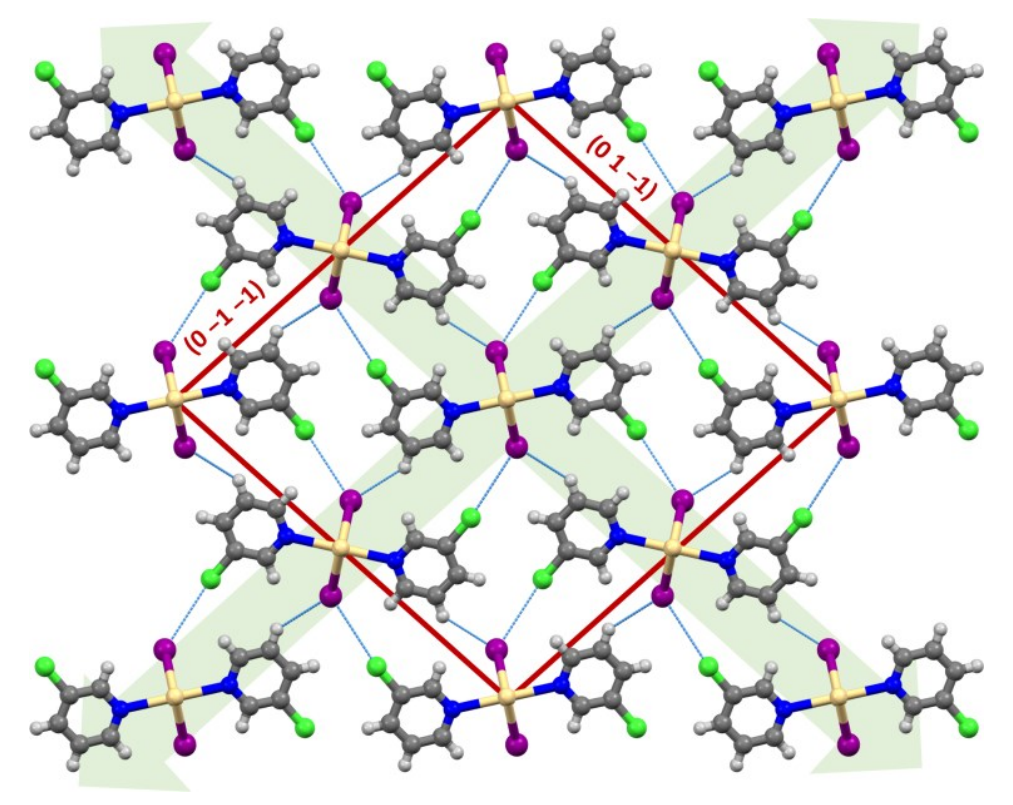

$\left[\mathrm{Cdl}_{2}(3-\mathrm{Clpy})_{2}\right]_{\mathrm{n}}(\mathbf{2})$ 


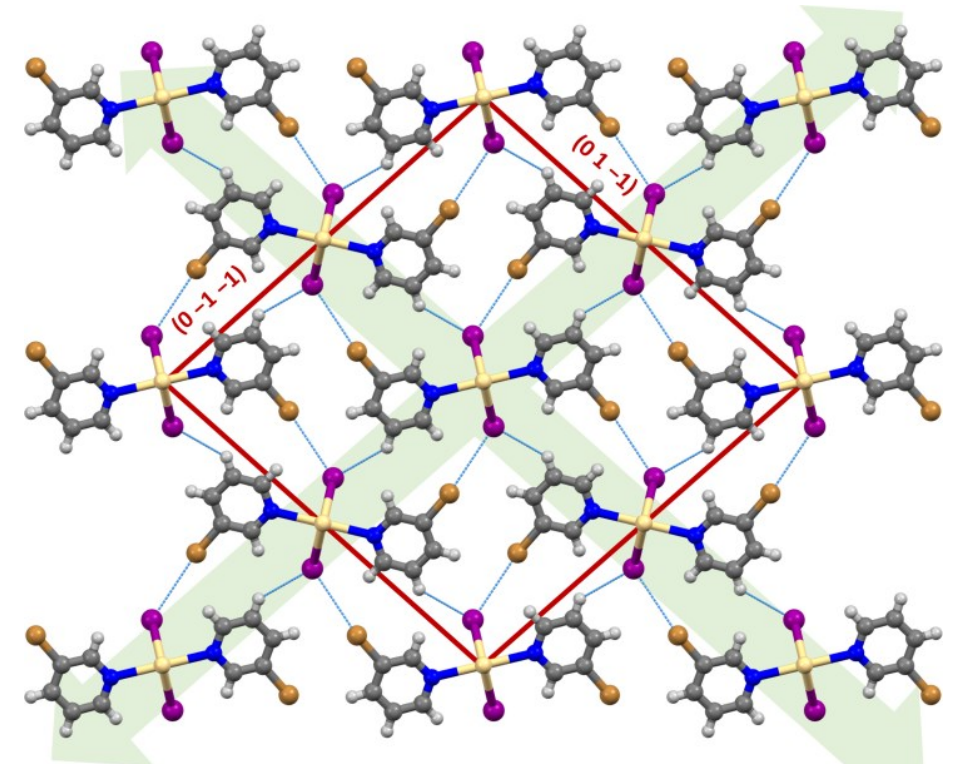

$\left[\mathrm{CdI}_{2}(3-\mathrm{Clpy})_{2}\right]_{\mathrm{n}}(\mathbf{3})$

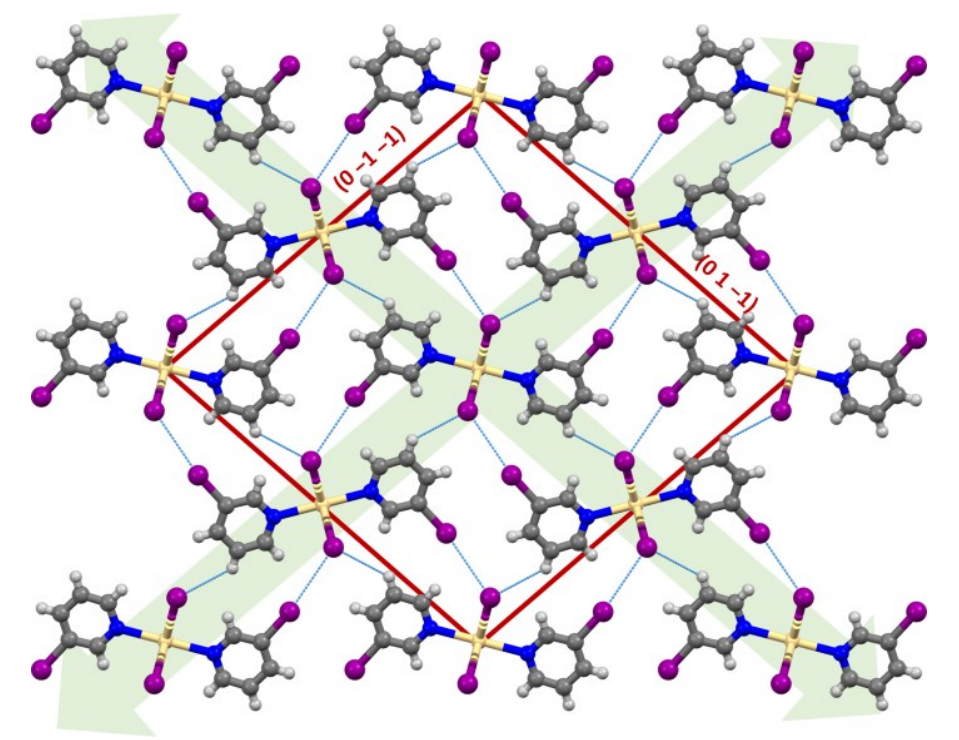

$\left[\mathrm{Cdl}_{2}(3-\mathrm{Ipy})_{2}\right]_{\mathrm{n}}(6)$

Figure S2. The relative orientation of adjacent polymeric chains (a view down the $a$ axis) in the crystal structures of 1-3 and 6, linked via halogen $(C-C l \cdots B r(C d) 1, C-C l \cdots|(C d) 2, C-B r \cdots|(C d) 3$ and $\mathrm{C}-|\cdots|(\mathrm{Cd}) 6$ ) and hydrogen bonds $(\mathrm{C}-\mathrm{H} \cdots \mathrm{Br}(\mathrm{Cd}) \mathbf{1}, \mathrm{C}-\mathrm{H} \cdots|(\mathrm{Cd}) \mathbf{2}, \mathrm{C}-\mathrm{H} \cdots|(\mathrm{Cd}) \mathbf{3}$ and $\mathrm{C}-\mathrm{H} \cdots \mid(\mathrm{Cd})$ 6) shown as blue dotted lines, forming a 2-D network in the directions orthogonal to the elongation of the crystal.

Crystal faces $(011) /(0-1-1) /(0-11) /(01-1)$ are indicated by red lines. Directions along which the mechanical force is applied are indicated by green arrows. 


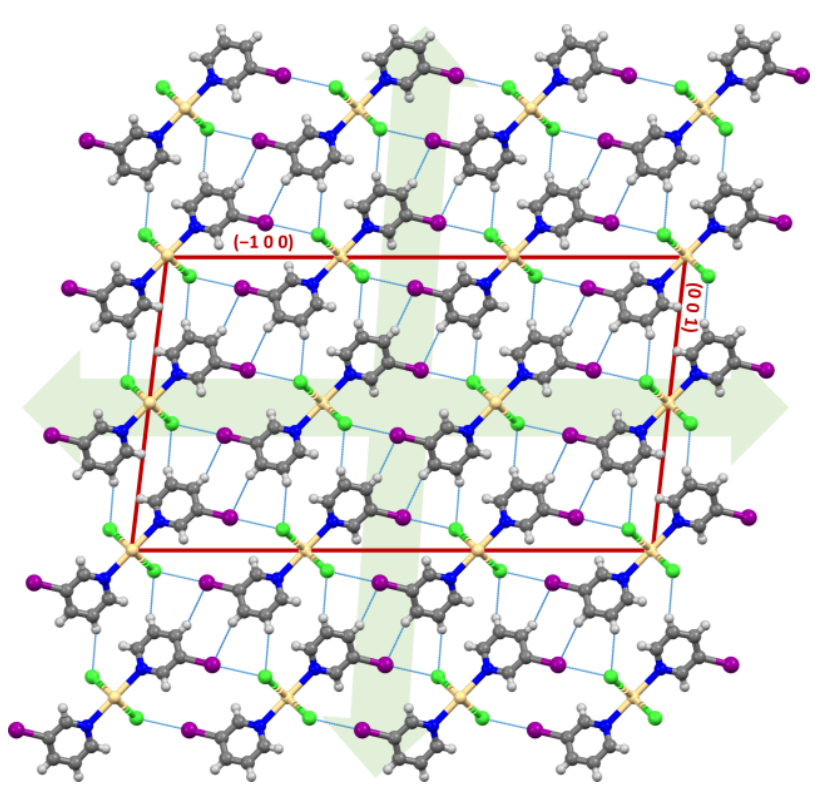

$\left[\mathrm{CdCl}_{2}(3-\mathrm{Ipy})_{2}\right]_{\mathrm{n}}(4)$

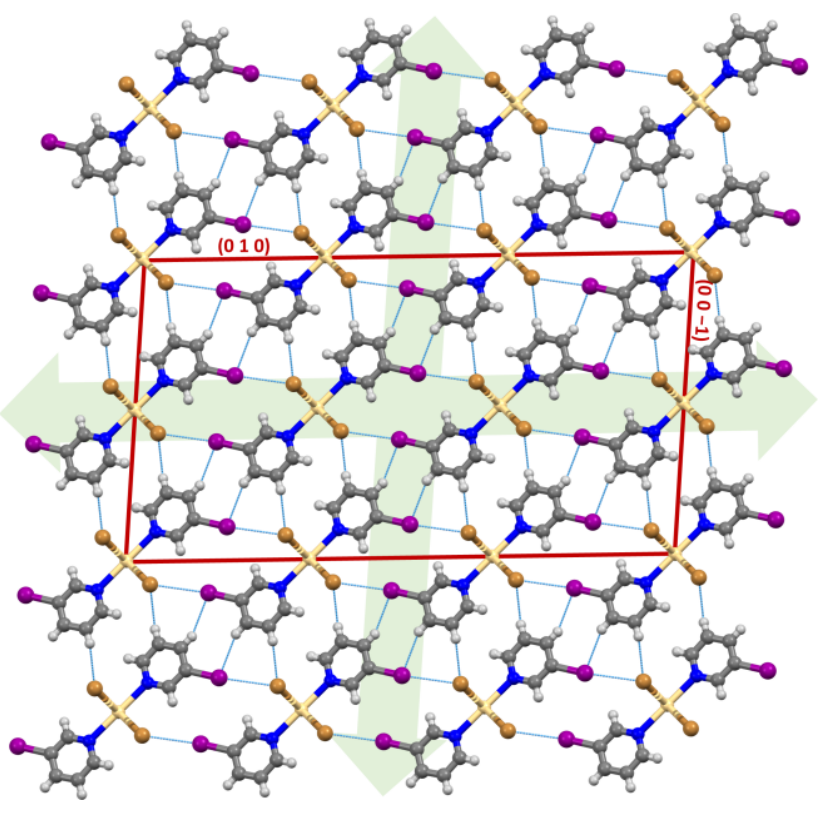

$\left[\mathrm{CdBr}_{2}(3-\mid \mathrm{py})_{2}\right]_{\mathrm{n}}(\mathbf{5})$

Figure S3. The relative orientation of adjacent polymeric chains (a view down the $b$ axis) in the crystal structure of 4 and 5 , linked via halogen $(C-1 \cdots C l(C d) 4$ and $C-1 \cdots \operatorname{Br}(C d) 5)$ and hydrogen bonds $(\mathrm{C}-\mathrm{H} \cdots \mathrm{I}$ and $\mathrm{C}-\mathrm{H} \cdots \mathrm{Cl}(\mathrm{Cd}), 4 ; \mathrm{C}-\mathrm{H} \cdots \mathrm{Br}(\mathrm{Cd})$ and $\mathrm{C}-\mathrm{H} \cdots \mathrm{I}, 5)$ shown as blue dotted lines, forming a 2-D network in the directions orthogonal to the direction of elongation of the crystal.

Crystal faces $(001) /(00-1) /(100) /(-100)$ are indicated by red lines. Directions along which the mechanical force is applied are indicated by green arrows. 


\section{Powder X-ray crystallography}

X-ray powder diffraction experiments were performed on a Philips PW 1850 diffractometer, $\mathrm{CuK \alpha}$ radiation, voltage $40 \mathrm{kV}$, and current $40 \mathrm{~mA}$. The patterns were collected in the angle region between $5^{\circ}$ and $50^{\circ}(2 \vartheta)$ with a step size of $0.02^{\circ}$. The X-ray powder diffraction (PXRD) of bulk samples of 4-6 was performed, and patterns were compared with the calculated ones. The comparison confirmed phase purity.

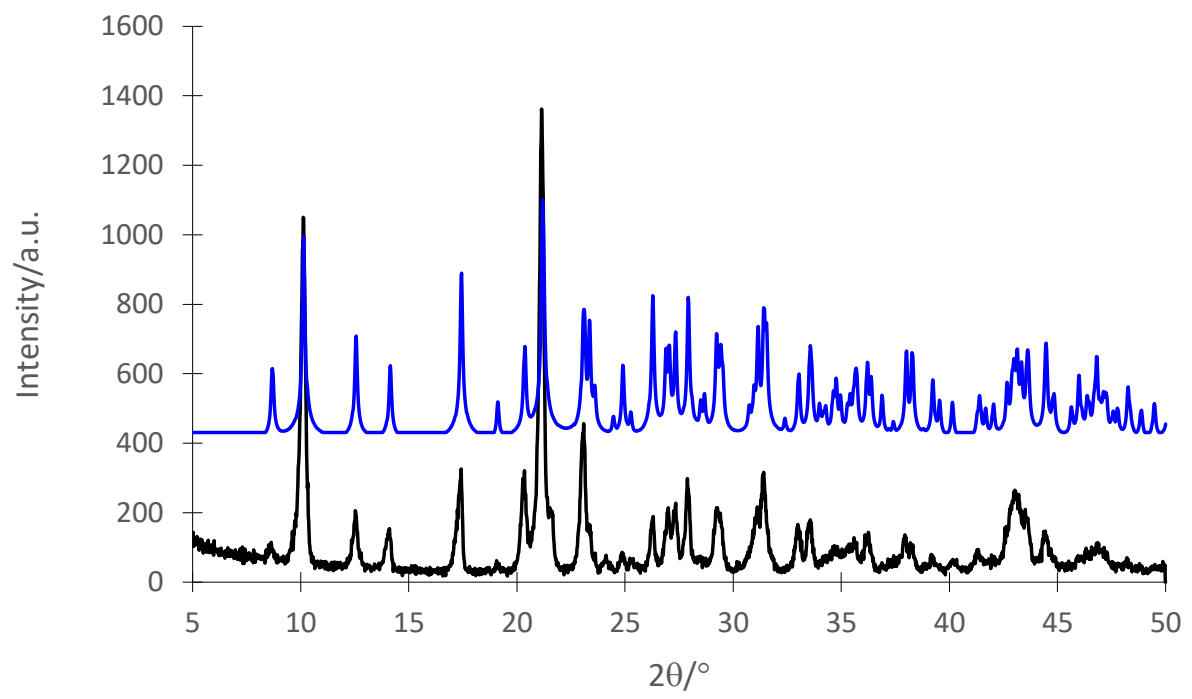

Figure S4. Experimental (black) and calculated (blue) PXRD traces of $\left[\mathrm{CdCl}_{2}(3-\mid \mathrm{py})_{2}\right]_{n}$ (4). 


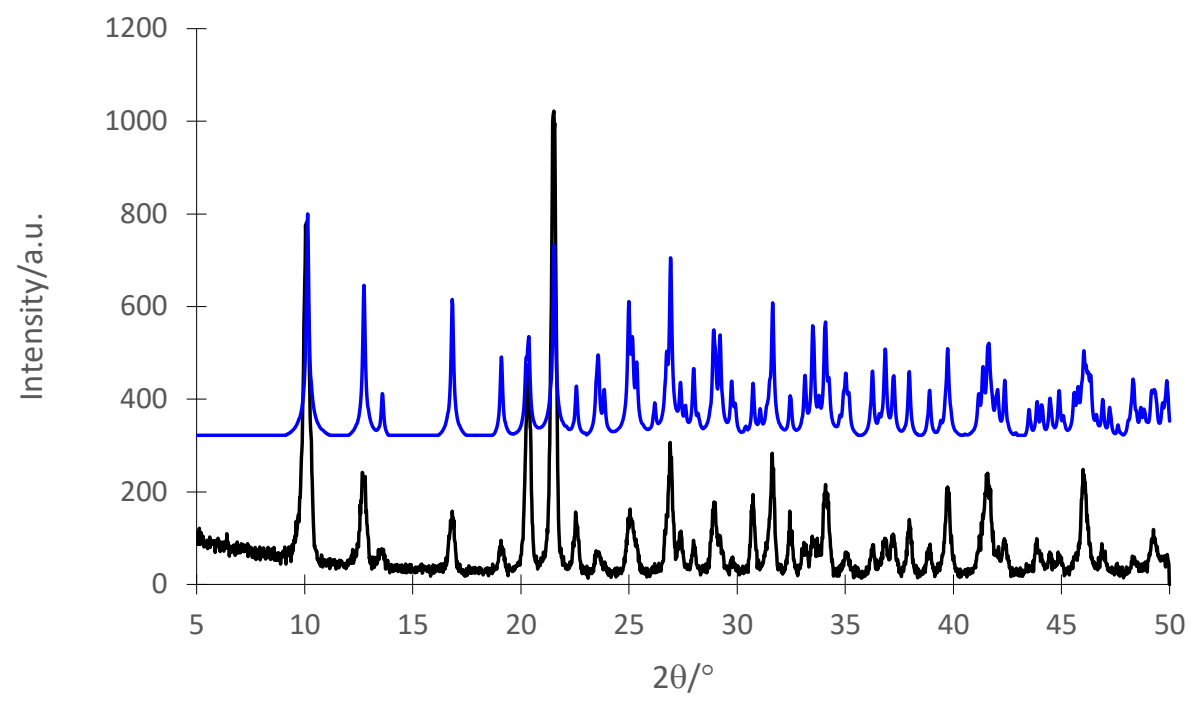

Figure S5. Experimental (black) and calculated (blue) PXRD traces of $\left[\mathrm{CdBr}_{2}(3-\mid \mathrm{py})_{2}\right]_{n}(5)$.

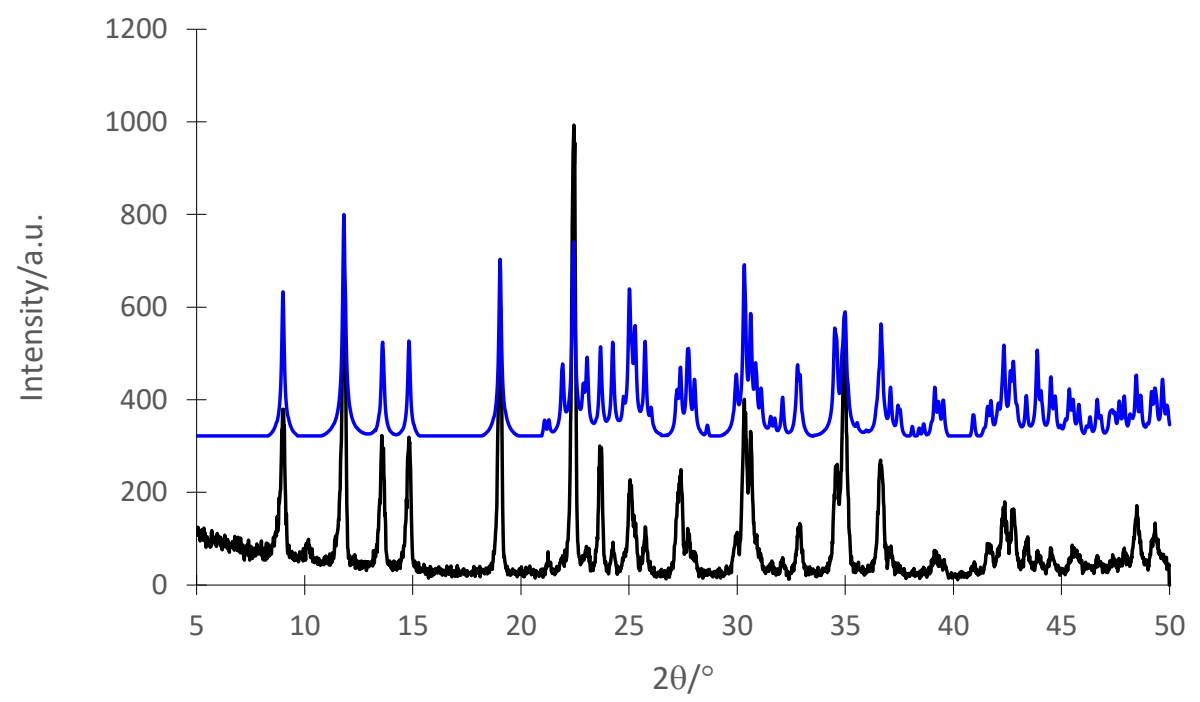

Figure S6. Experimental (black) and calculated (blue) PXRD traces of $\left[\mathrm{Cdl}_{2}(3-\mathrm{Ipy})_{2}\right]_{n}(\mathbf{6})$. 


\section{Differential Scanning Calorimetry (DSC)}

Differential Scanning Calorimetry was performed on DSC instrument Mettler-Toledo DSC DSC823e. For each sample (1, 2, 3 and 5) two measurements were performed, on straight and on randomly bent crystals. The crystals were placed in aluminium pans $(40 \mu \mathrm{L})$, heated in flowing nitrogen $\left(120 \mathrm{~mL} \mathrm{~min}{ }^{-1}\right)$ from room temperature up to $300{ }^{\circ} \mathrm{C}$ at a rate of $10{ }^{\circ} \mathrm{C} \mathrm{min}{ }^{-1}$. Data collection and analysis were performed using the program package STARe Software 15.01 MettlerToledo $\mathrm{GmbH}, 2015$. Comparison of thermal behavior of straight and bent crystals are shown in Figures S7-S8.

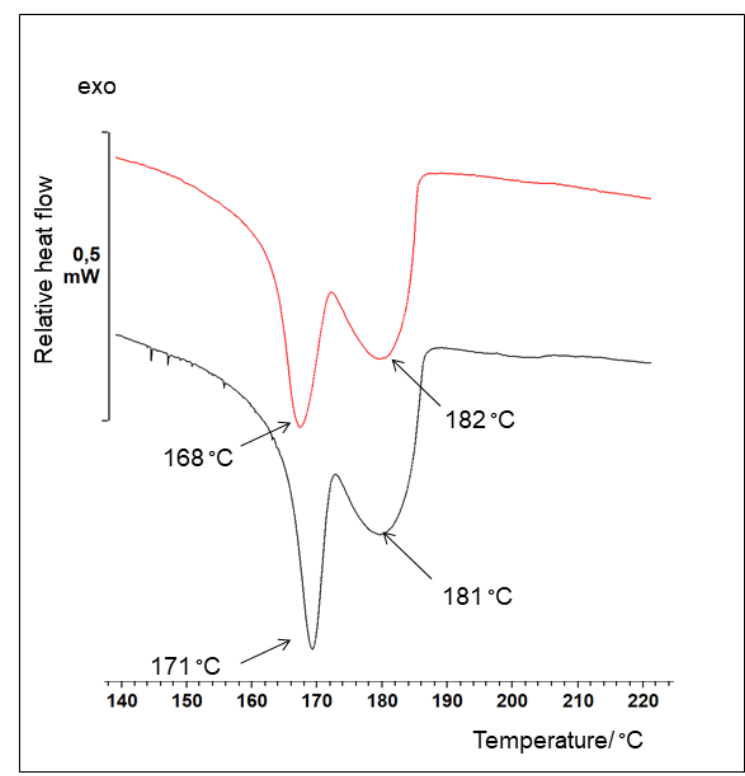

(a)

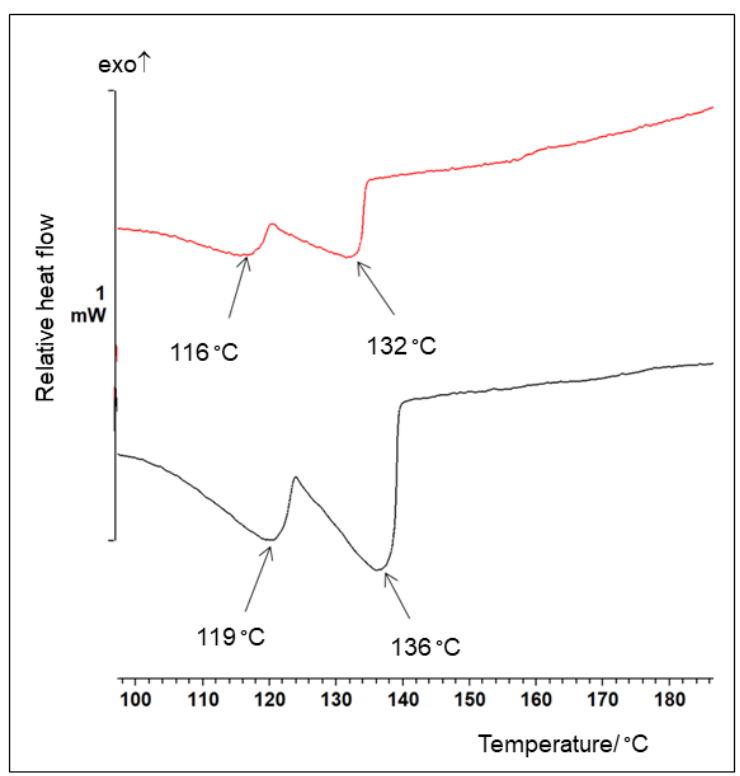

(b)

Figure S7. DSC curves of straight (black) and bent (red) crystals of $\left[\mathrm{CdBr}_{2}(3-\mathrm{Clpy})_{2}\right]_{\mathrm{n}}(\mathbf{1})(\mathrm{a})$ and $\left[\mathrm{Cdl}_{2}(3-\mathrm{Clpy})_{2}\right]_{\mathrm{n}}(2)(\mathrm{b})$. 


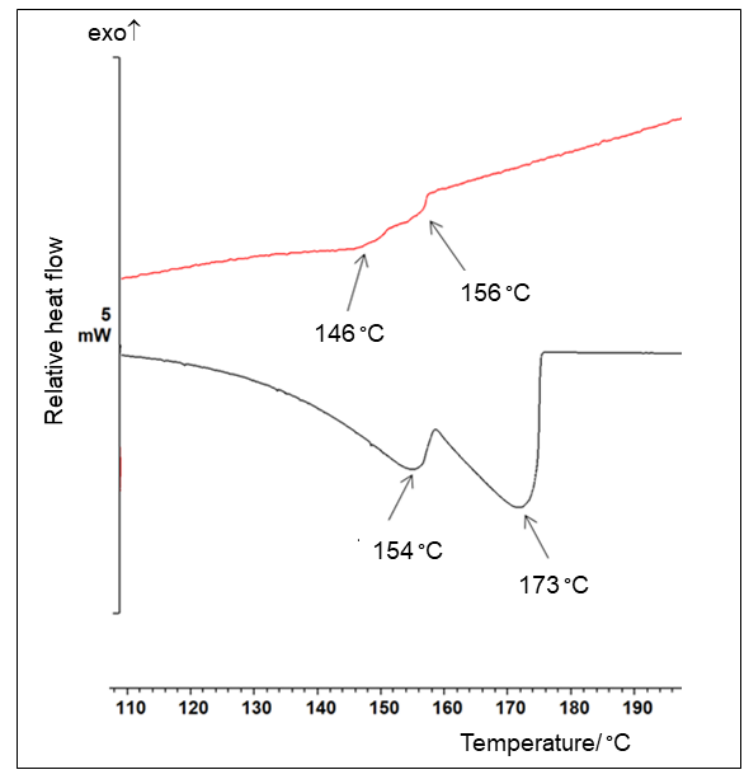

(a)

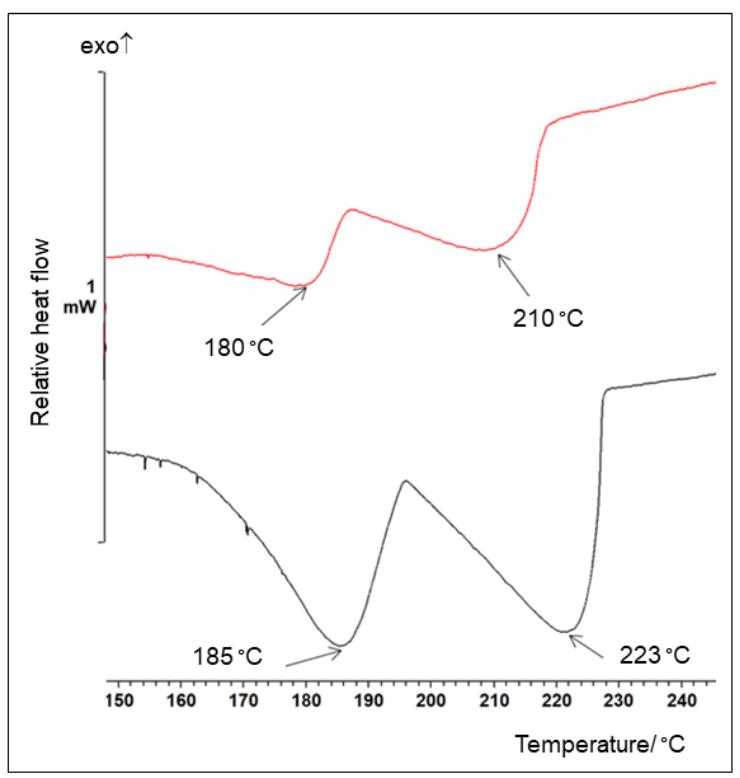

(b)

Figure S8. DSC curves of straight (black) and bent (red) $\left[\mathrm{Cdl}_{2}(3-\mathrm{Brpy})_{2}\right]_{\mathrm{n}}(\mathbf{3})(\mathrm{a})$ and $\left[\mathrm{CdB}_{2}(3-\right.$ $\left.(p y)_{2}\right]_{n}(5)(b)$. 


\section{Thermogravimetric analysis (TGA)}

Thermogravimetric analysis was performed using a simultaneous TGA-DTA analyzer MettlerToledo TGA/DSC 3+. The powder samples (1-6) were placed in aluminium pans $(40 \mu \mathrm{L})$, heated in flowing nitrogen $\left(120 \mathrm{~mL} \mathrm{~min}{ }^{-1}\right)$ from room temperature up to $300{ }^{\circ} \mathrm{C}$ at a rate of $10^{\circ} \mathrm{C} \mathrm{min}^{-1}$. Data collection and analysis were performed using the program package STARe Software 15.01 MettlerToledo $\mathrm{GmbH}, 2015$.

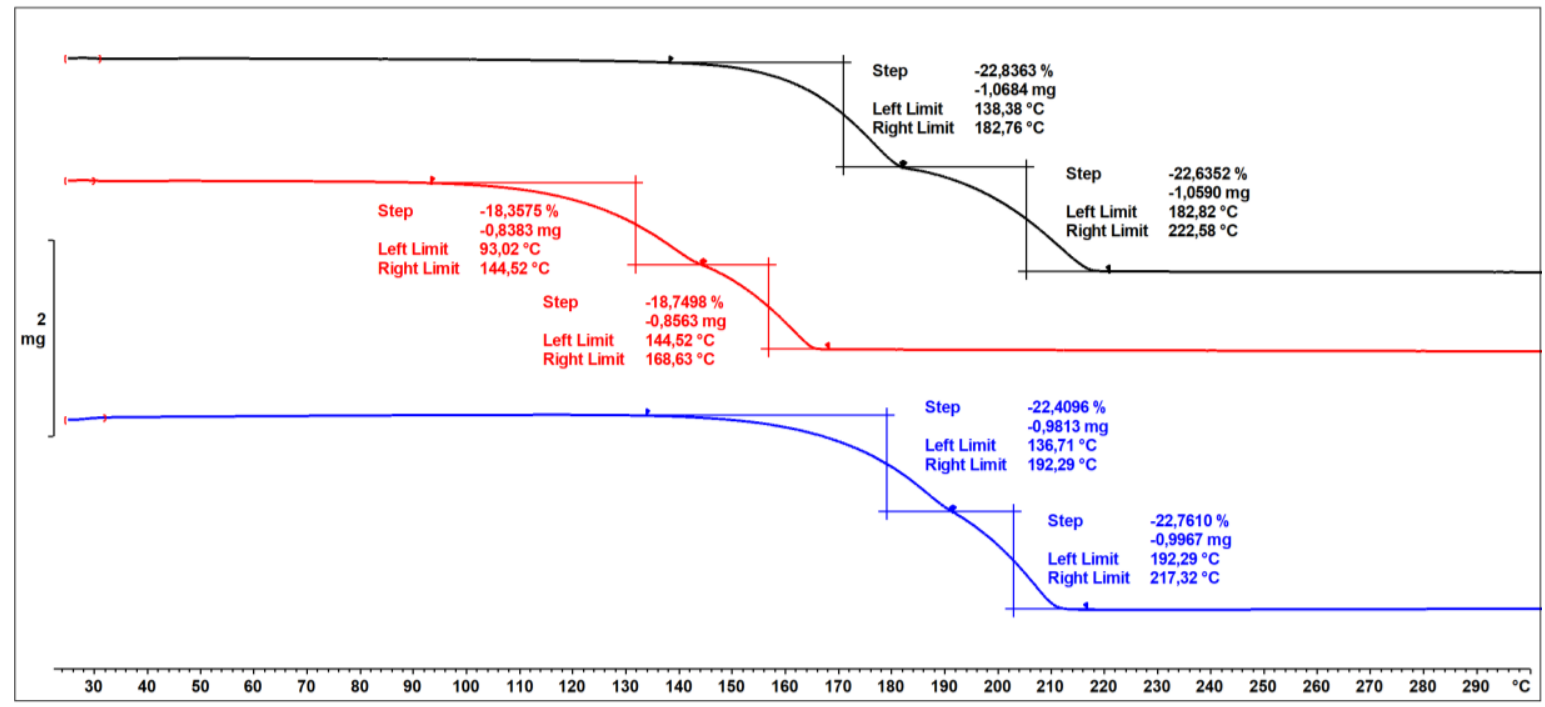

Figure 59. TGA curves of $\left[\mathrm{CdBr}_{2}(3-\mathrm{Clpy})_{2}\right]_{n}(\mathbf{1})$ (black), $\left[\mathrm{Cdl}_{2}(3-\mathrm{Clpy})_{2}\right]_{n}(\mathbf{2})(\mathrm{red})$ and $\left[\mathrm{Cdl}_{2}(3-\right.$ Brpy $\left.)_{2}\right]_{n}$ (3) (blue).

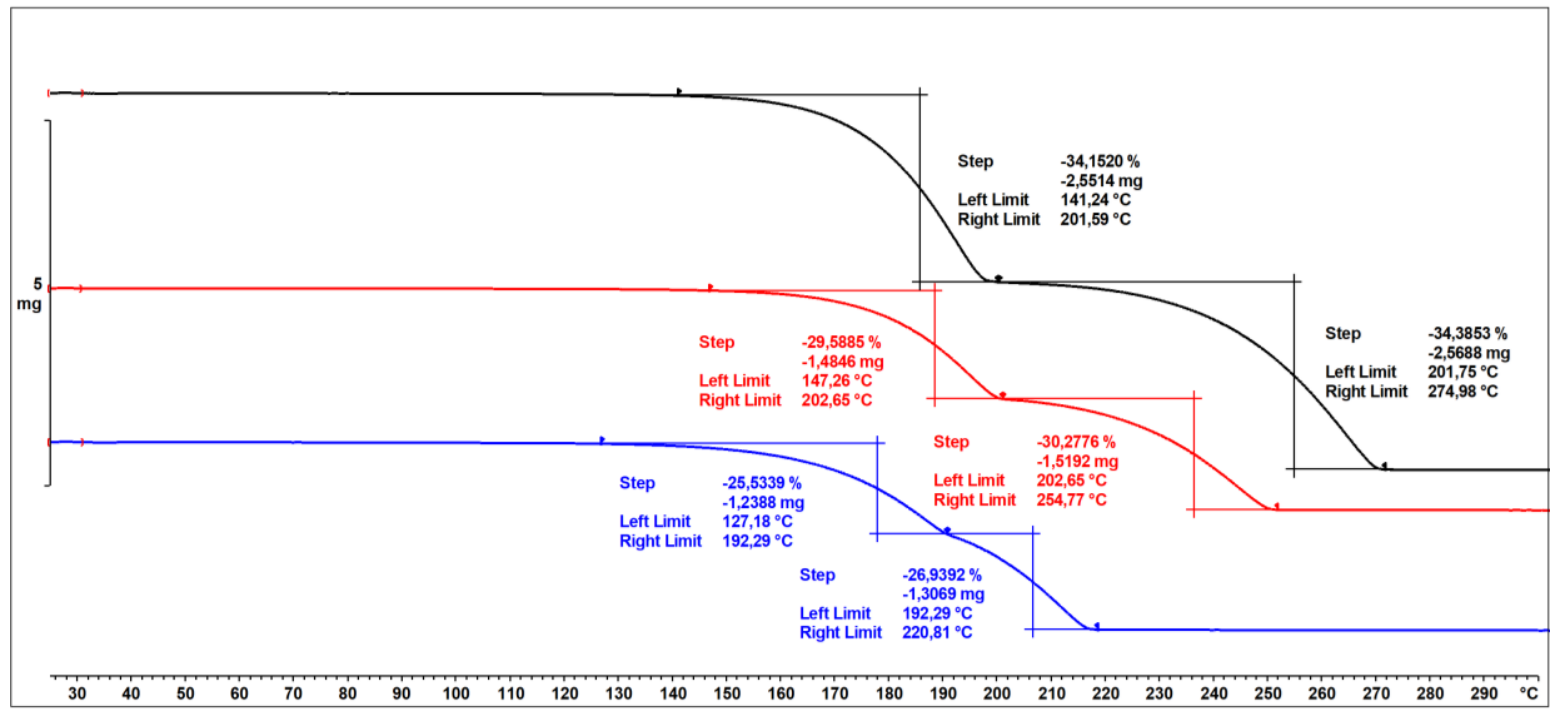

Figure S10. TGA curves of $\left[\mathrm{CdCl}_{2}(3-\mathrm{Ipy})_{2}\right]_{n}(4)$ (black), $\left[\mathrm{CdBr}_{2}(3-\mathrm{Ipy})_{2}\right]_{n}(5)$ (red) and $\left[\mathrm{CdI}_{2}\left(3-\mathrm{Ipy}_{2}\right]_{n}\right.$ (6) (blue). 


\section{Crystal bending experiments}

Crystal bending experiments were performed using a modified three-point bending procedure. For that purpose, selected crystals were placed on a glass slide, immersed in a small amount of paratone oil to prevent crystal damage due to usage of metal accessories. Crystal was held from one side with a pair of metal tweezers while the mechanical force was applied from the opposite side using a metal needle. For crystals of each compound mechanical force was applied on both pairs of most prominent crystal faces (parallel to the elongation of the crystal), to determine the relationship between of the direction of applied mechanical force and the nature of mechanical response. All bending experiments were carried out using a Dino-Lite Edge Digital Microscope (model AM4815ZT), and the recordings were taken and processed using DinoCapture 2.0 software (version 1.5.28.D).

For the crystals that showed substantial elastic response, the extent of elasticity was quantified using Euler-Bernoulli equation. ${ }^{6}$ For that purpose, thickness $(t)$ of the crystals prior the bending, together with distance between the tips of metal tweezers holding the bent crystal $(L)$ and maximal displacement $\left(h_{\max }\right)$ at a point of maximal curvature, i.e. just before the breakage of a crystal, were measured (Figure S11). The radius of circle describing curvature of bent crystal was calculated using geometrical construction presented in Figure S11 [1, 2]:

$$
\begin{gathered}
R^{2}=\left(\frac{L}{2}\right)^{2}+\left(R-h_{\max }\right)^{2} \\
R=\frac{\left(\frac{L}{2}\right)^{2}+h_{\max }^{2}}{2 h_{\max }}
\end{gathered}
$$

The bending strain was calculated from Euler-Bernoulli equation $[3]^{6}$ (considering pure bending without shear component):

$$
\varepsilon(\%)=\frac{\frac{t}{2}}{R} \cdot 100
$$




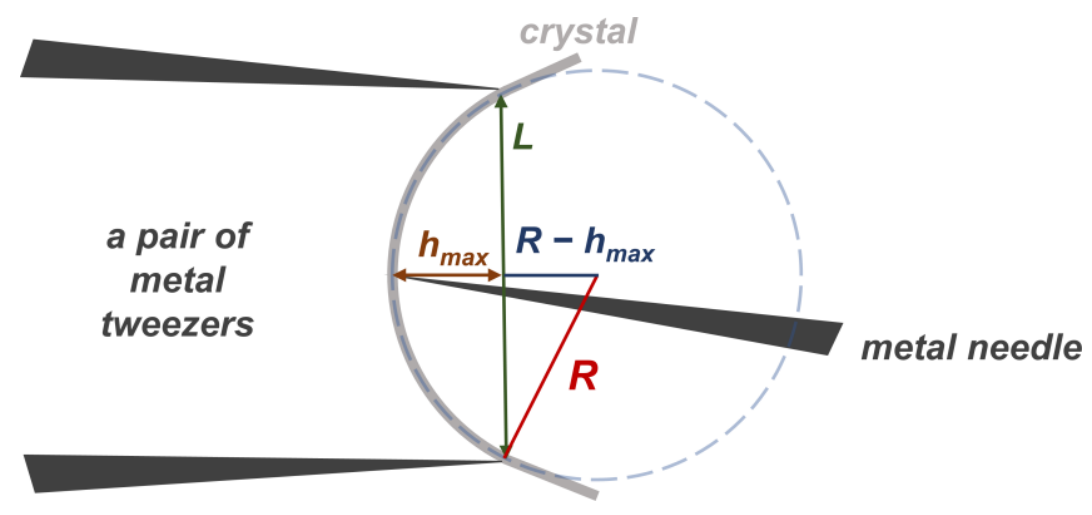

Figure S11. Schematic representation of three-point bending experiment highlighting measured (green arrow, distance between tips of metal tweezers, L; brown arrow, maximal displacement, $h_{\max }$ ) and calculated (red line, radius of the circle approximating the curvature of the bent crystal, $R$ ) geometrical parameters needed for determining bending strain $(\varepsilon)$. 
a)

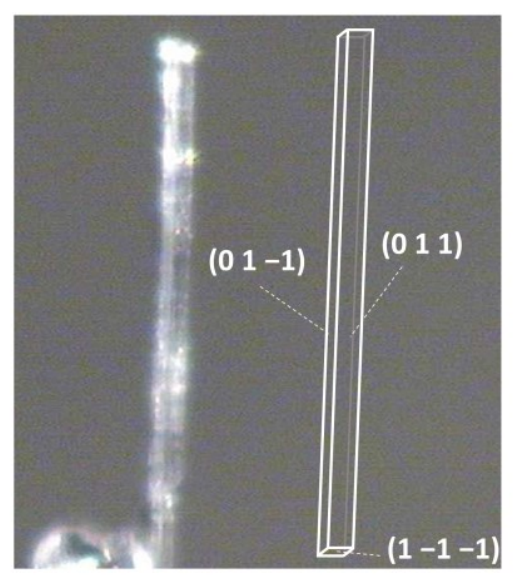

b)

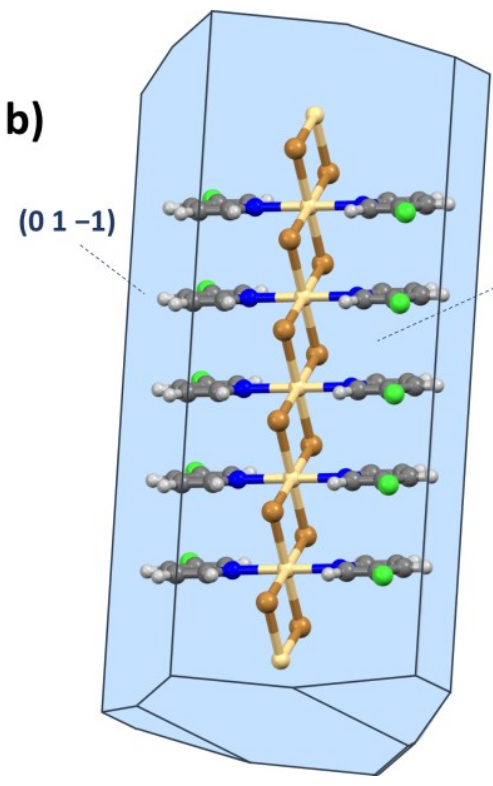

(0 101 )

Figure S12. Face indexing (a) and calculated BFDH morphology (using Mercury 4.3.1) (b) for $\left[\mathrm{CdBr}_{2}(3-\mathrm{Clpy})_{2}\right]_{n}(\mathbf{1})$.
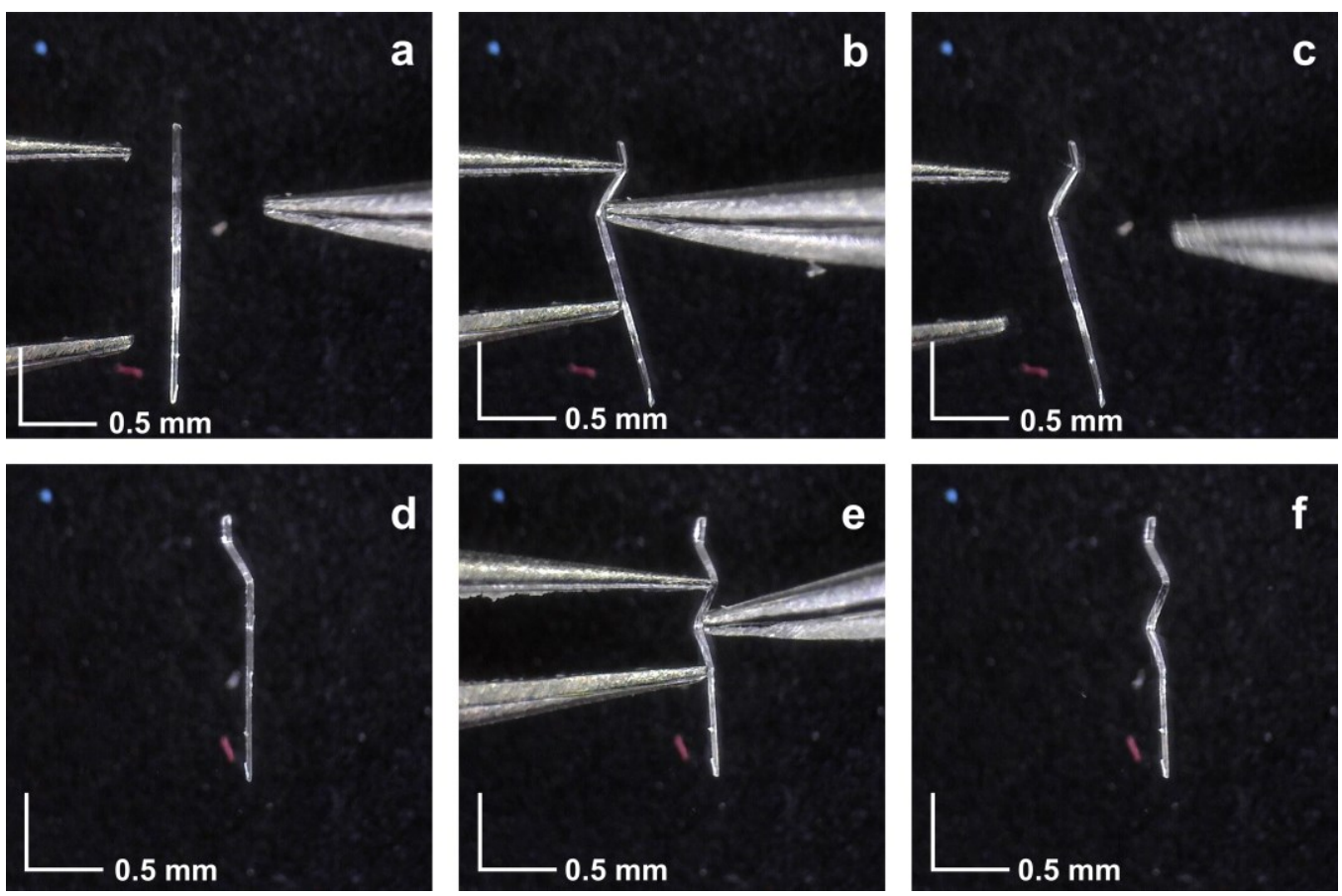

Figure S13. Bending experiment with $\left[\mathrm{CdBr}_{2}(3-\mathrm{Clpy})_{2}\right]_{n}$ (1) (images magnified 70 times), by applying mechanical force on (0-11/01-1) pair of crystal faces $(a-c)$, and (011/0-1-1) pair of crystal faces $(d-f)$. Crystal bends plastically over both pairs of crystal faces once mechanical force is applied. 
a)

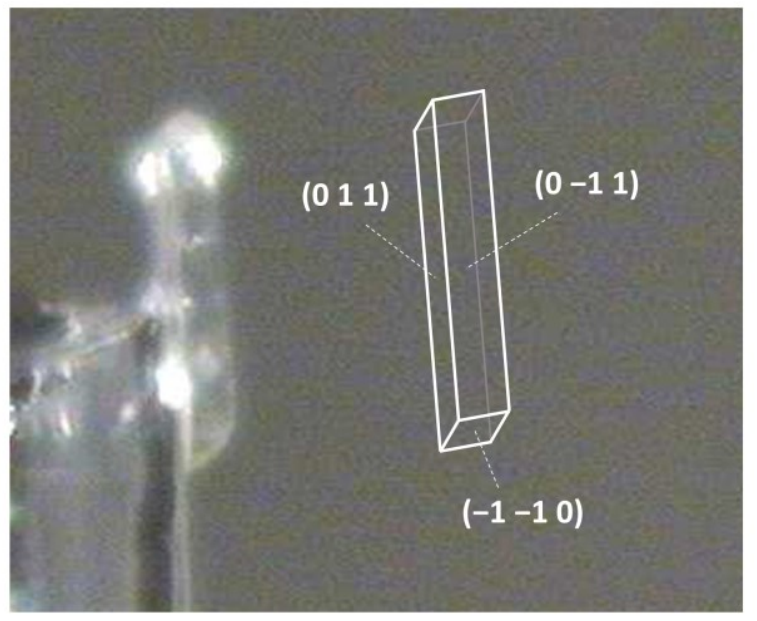

b)

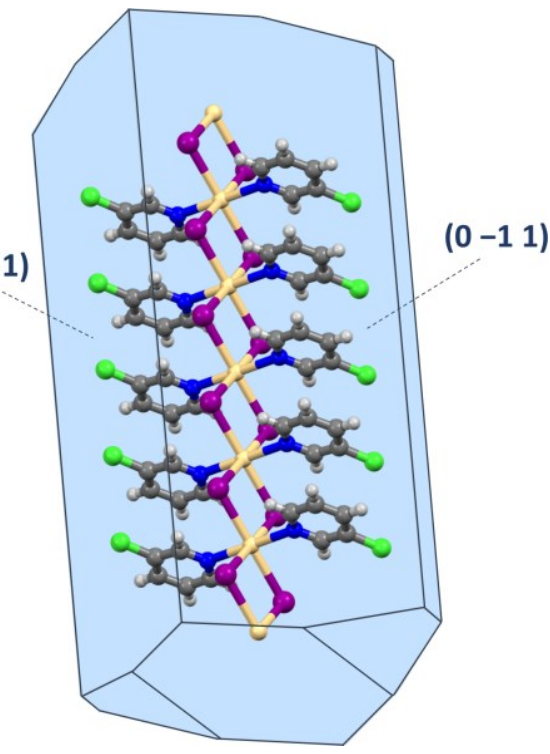

Figure S14. Face indexing (2) (a) and calculated BFDH morphology (using Mercury 4.3.1) (b) for $\left[\mathrm{Cdl}_{2}(3-\mathrm{Clpy})_{2}\right]_{n}$.
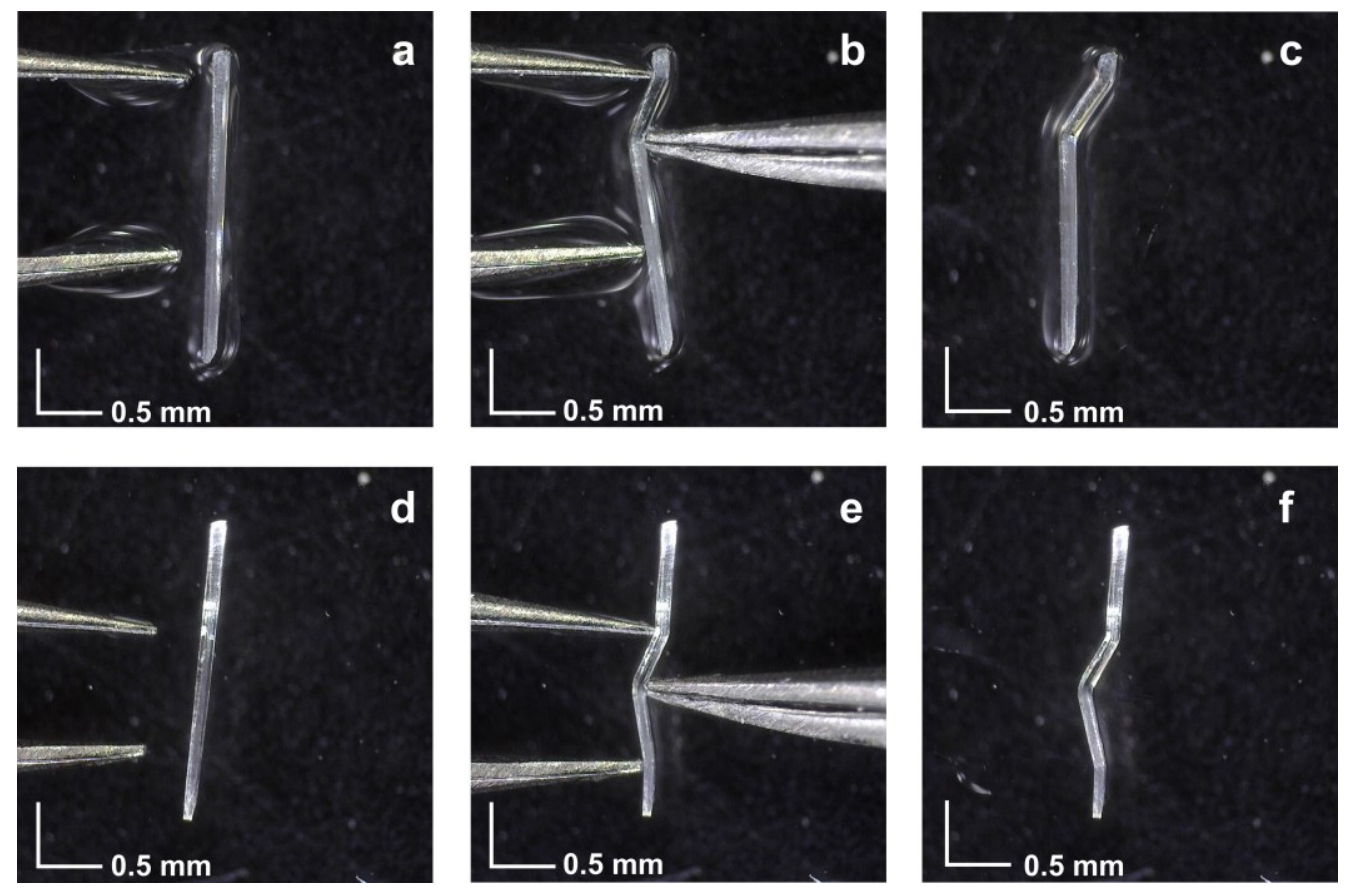

Figure S15. Bending experiment with $\left[\mathrm{Cdl}_{2}(3-\mathrm{Clpy})_{2}\right]_{n}$ (2) (images magnified 70 times), by applying mechanical force on (011/0-1-1) pair of crystal faces (a-c), and (01-1/0-11) pair of crystal faces $(d-f)$. Crystal bends plastically over both pairs of crystal faces once mechanical force is applied. 
(a)

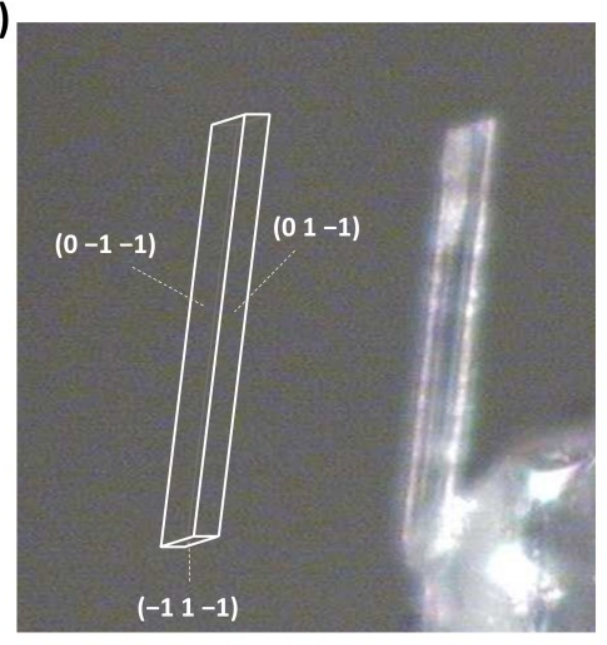

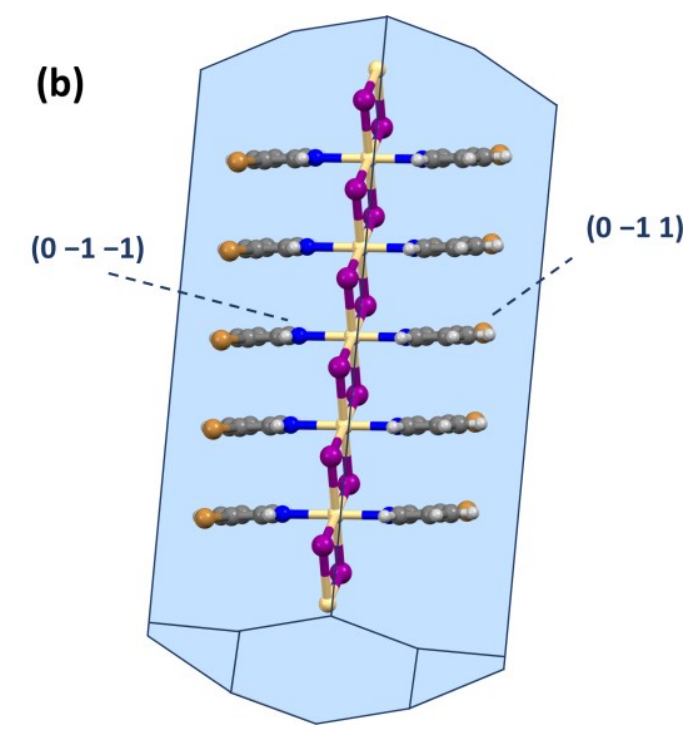

(b)

Figure S16. Face indexing (a) and calculated BFDH morphology (using Mercury 4.3.1) (b) for crystals of $\left[\mathrm{Cdl}_{2}\left(3-\mathrm{Brpy}_{2}\right]_{n}(3)\right.$.
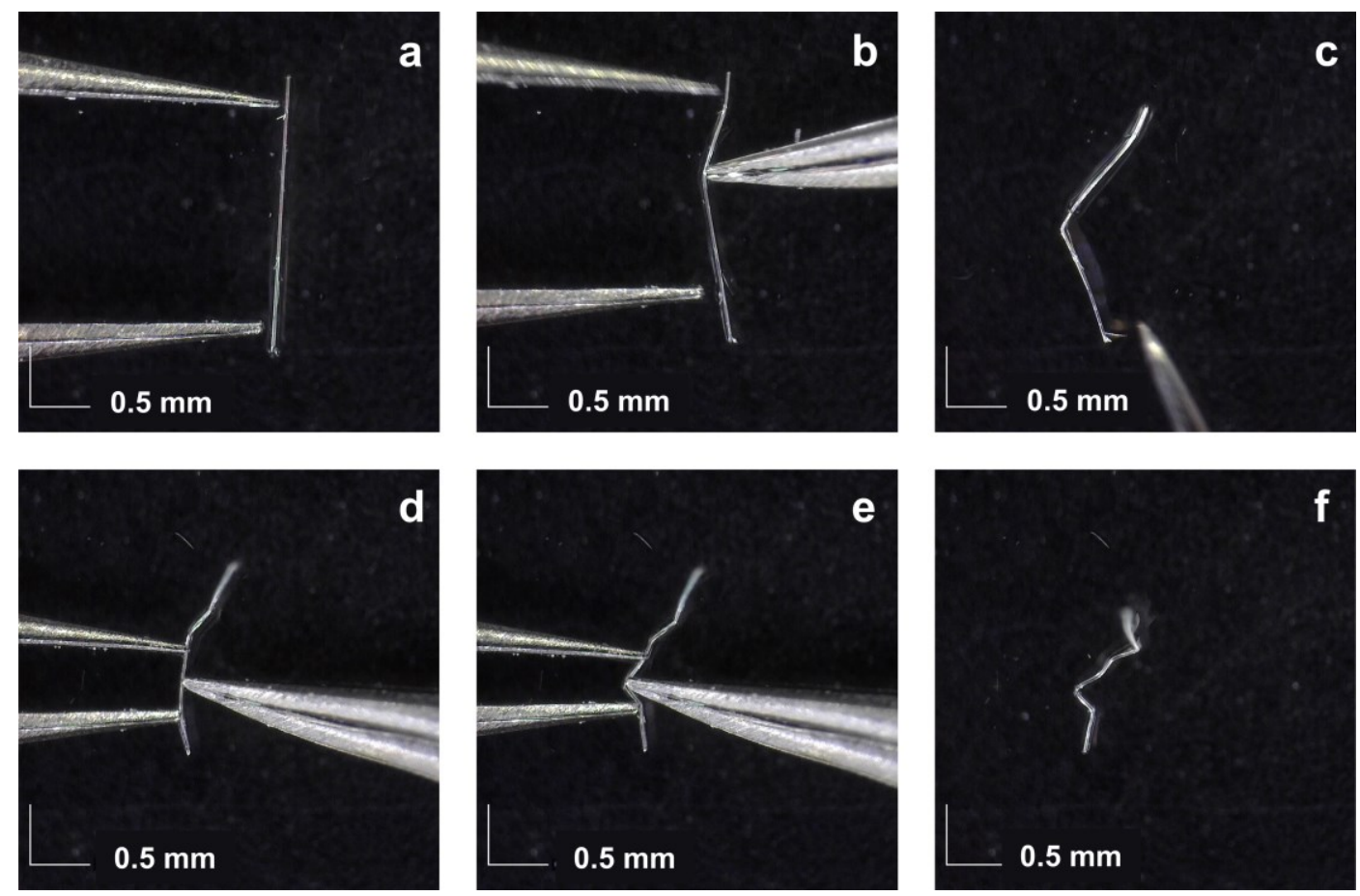

Figure S17. Bending experiment with $\left[\mathrm{Cdl}_{2}(3-\mathrm{Brpy})_{2}\right]_{\mathrm{n}}$ (3) (images magnified 70 times), by applying mechanical force on (011/0-1-1) pair of crystal faces (a-c), and (01-1/0-11) pair of crystal faces (d-f). Crystal bends plastically once mechanical force is applied. 
(a)

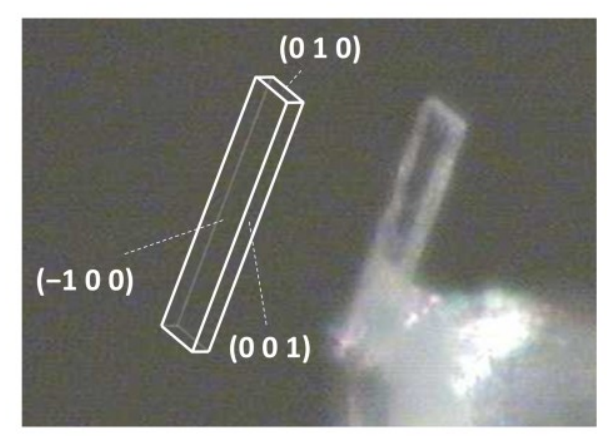

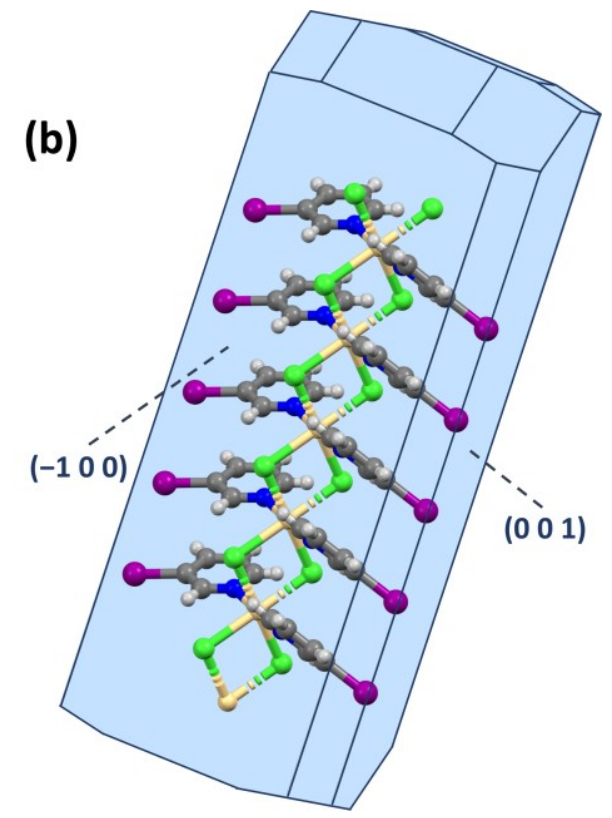

Figure S18. Face indexing (a) and calculated BFDH morphologies (using Mercury 4.3.1) (b) for crystals of $\left[\mathrm{CdCl}_{2}(3-\mathrm{Ipy})_{2}\right]_{n}(4)$.

Table S5. Geometrical parameters used to calculate bending strain $(\varepsilon)$. The mean value of the bending strain (shown in red) was determined on the basis of measurements of five different samples for the compound 4 by applying mechanical force on (100/-100) pair of crystal faces. Thickness $(t)$ of the selected crystals was measured before bending, length $(L)$ and maximal displacement $\left(h_{\max }\right)$ were measured at the point of maximal curvature (see Figure S19 below).

\begin{tabular}{cccccc}
\hline Sample & $\overline{\boldsymbol{t}} /$ & $\boldsymbol{L} /$ & $\boldsymbol{h}_{\max }$ & $\boldsymbol{R} / \mathbf{m m}$ & $\boldsymbol{\varepsilon} / \%$ \\
\hline \hline $\mathbf{4 - 1}$ & 0.009 & 0.671 & 0.035 & 1.621 & $\mathbf{0 . 2 7 8}$ \\
$\mathbf{4 - 2}$ & 0.008 & 0.363 & 0.011 & 1.503 & $\mathbf{0 . 2 5 5}$ \\
$\mathbf{4 - 3}$ & 0.010 & 0.532 & 0.020 & 1.779 & $\mathbf{0 . 2 7 2}$ \\
$\mathbf{4 - 4}$ & 0.015 & 0.794 & 0.025 & 3.165 & $\mathbf{0 . 2 3 7}$ \\
$\mathbf{4 - 5}$ & 0.010 & 0.669 & 0.035 & 1.616 & $\mathbf{0 . 3 2 0}$ \\
\hline & & & & average & $\mathbf{0 . 2 7 2} \pm \mathbf{0 . 0 3 0}$ \\
\hline
\end{tabular}



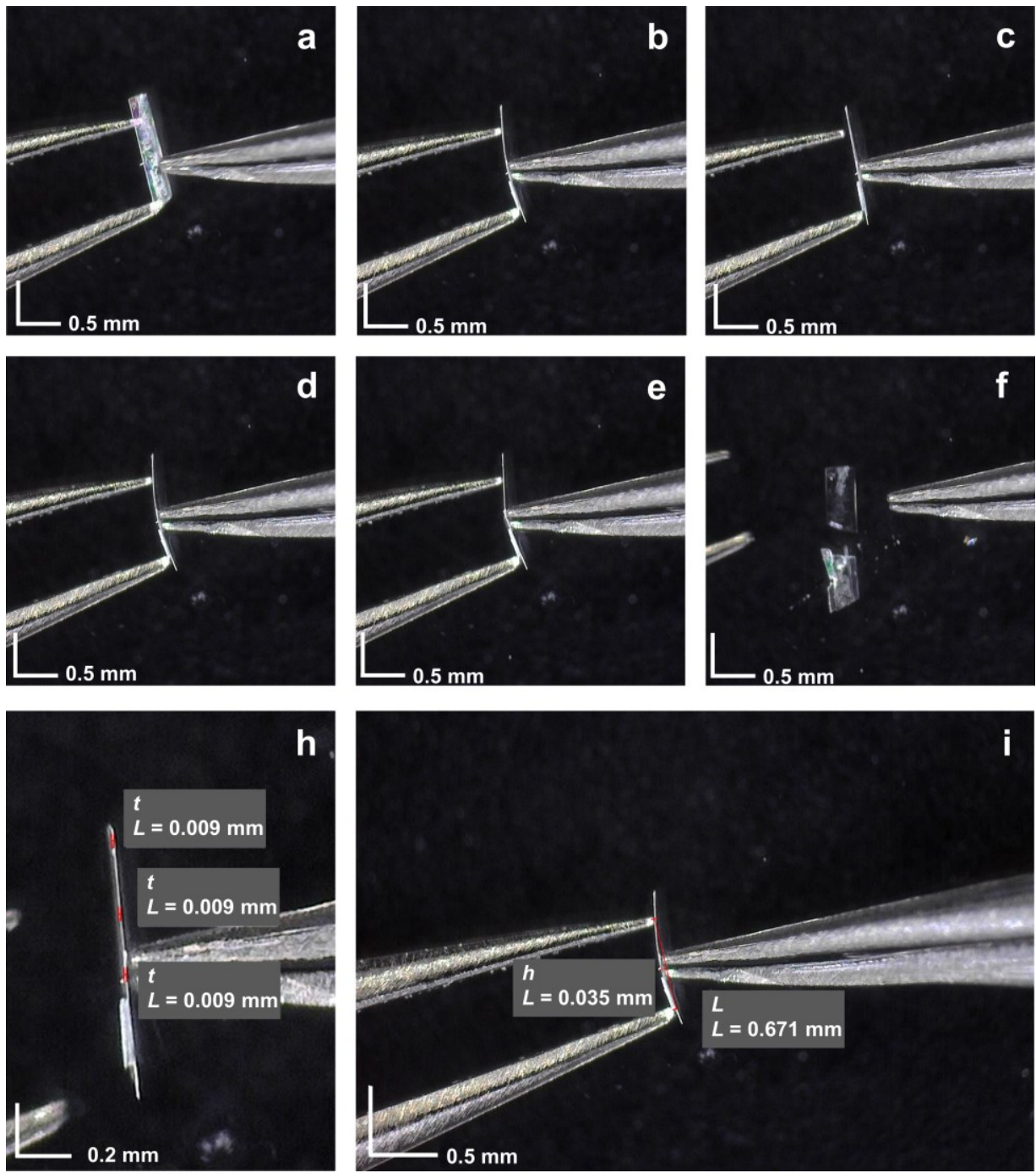

Figure S19. Bending experiment with $\left[\mathrm{CdCl}_{2}(3-\mathrm{Ipy})_{2}\right]_{n}$ (4, sample 4-1, images magnified 70 times), by applying mechanical force on (100/-100) pair of crystal faces, $\varepsilon=0.28 \%$. Slight elastic bending of the crystal followed by relaxation $(a-c)$; crystal fractures once bent over the critical radius ( $d-$ f). Geometrical parameters: (g) thickness $t$, (h) length $L$ and maximal displacement $h$.
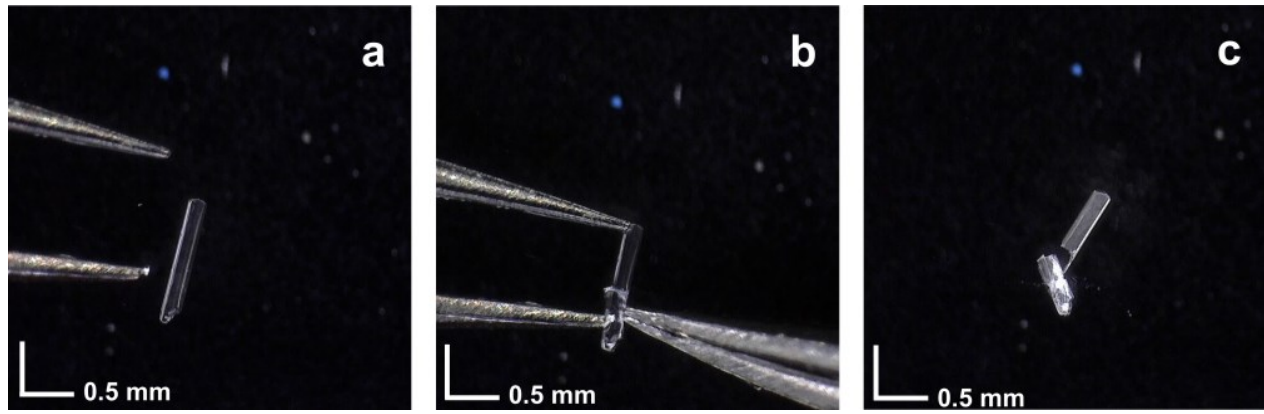

Figure S20. Bending experiment with $\left[\mathrm{CdCl}_{2}(3-\mathrm{I} \mathrm{py})_{2}\right]_{\mathrm{n}}$ (4) (images magnified 70 times). Crystal fractures once mechanical force is applied on (001/00-1) pair of crystal faces $(a-c)$. 
(a)

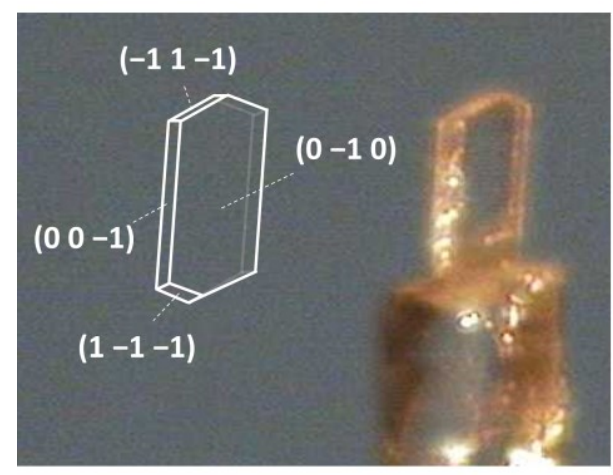

(b)

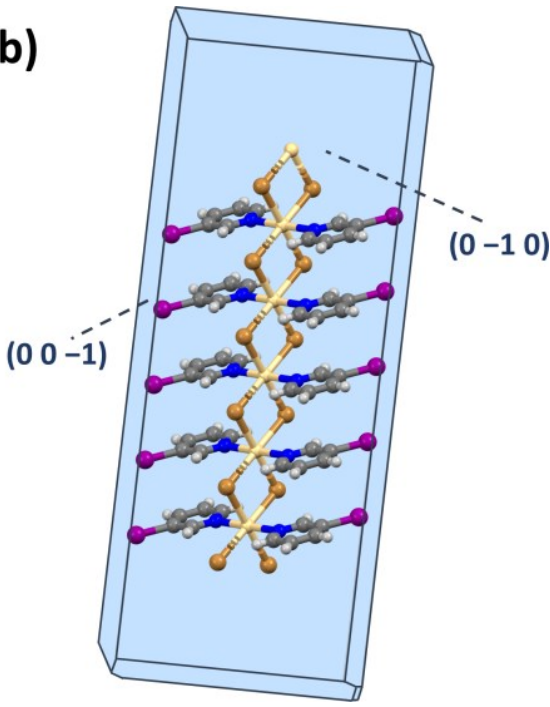

Figure S21. Face indexing (a) and calculated BFDH morphology (using Mercury 4.3.1) (b) for $\left[\mathrm{CdBr}_{2}(3-\mathrm{Ipy})_{2}\right]_{n}(5)$.
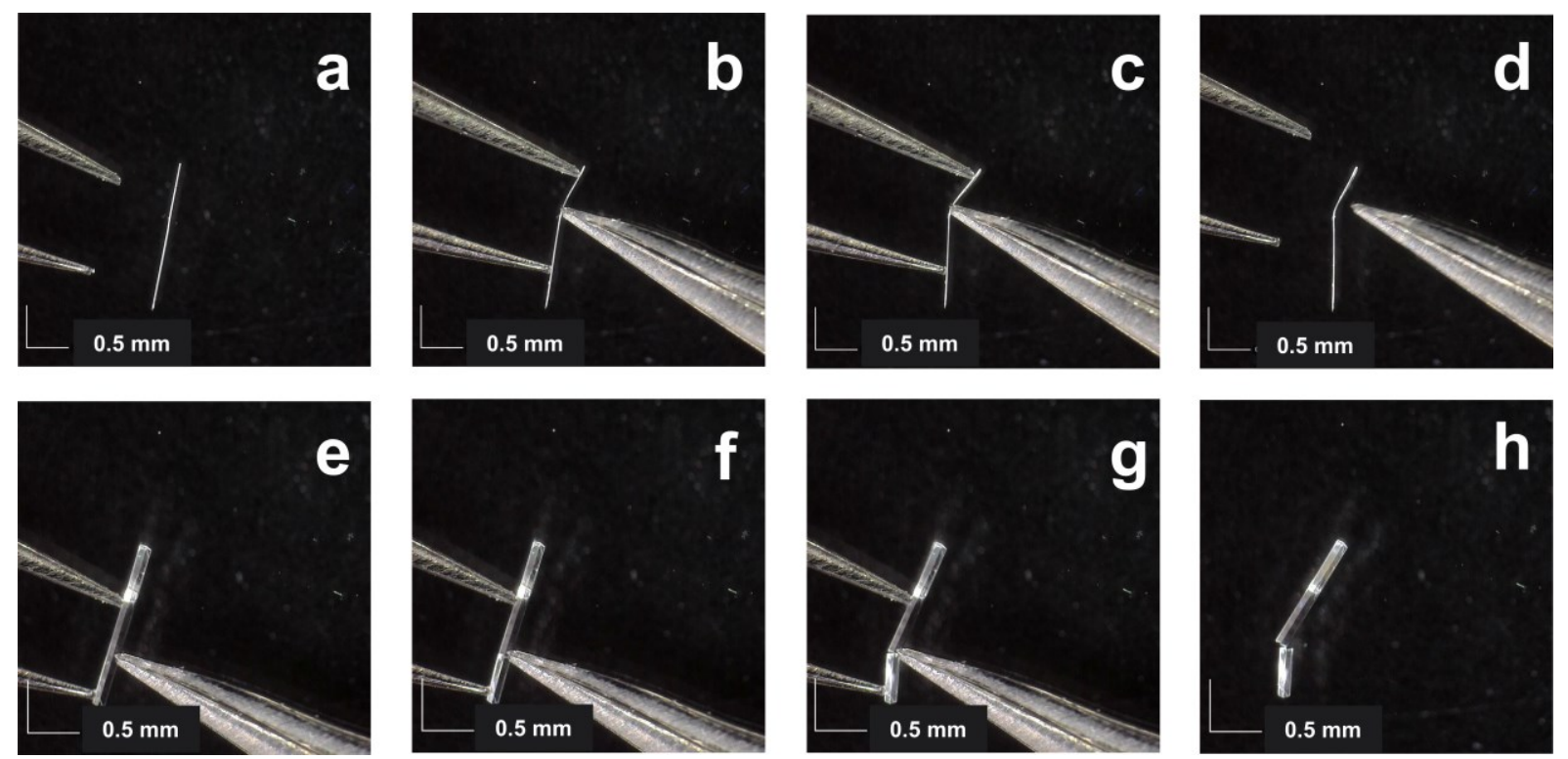

Figure S22. Bending experiment with $\left[\mathrm{CdBr}_{2}(3-\mathrm{Ipy})_{2}\right]_{n}$ (5, images magnified 70 times). Plastic bending of the crystal observed while mechanical force is applied on the $(010) /(0-10)$ pair of crystal faces (a-d); crystal fractures once mechanical force is applied on the (001)/(00-1) pair of crystal faces $(\mathrm{d}-\mathrm{h})$. Bending experiment (presented through $\mathrm{a}-\mathrm{h}$ ) was performend on the same crystal to clearly present two different mechanical behaviours; mechanical force $(d-h)$ was exerted on the part of the crystal that was ineffected by plastic deformation. 
(a)

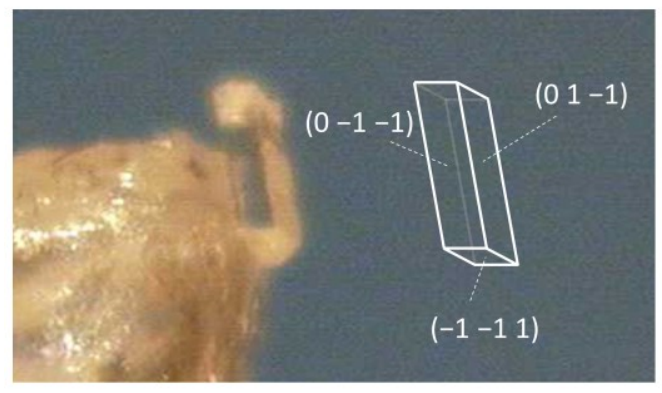

(b)

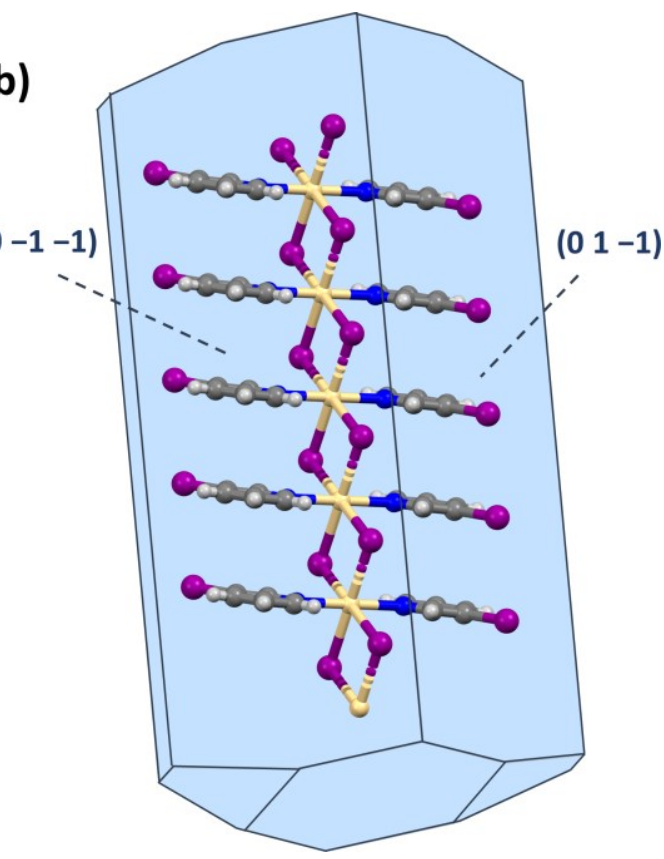

Figure S23. Face indexing (a) and calculated BFDH morphology (using Mercury 4.3.1) (b) for $\left[\mathrm{Cdl}_{2}(3-\mathrm{Ipy})_{2}\right]_{n}(6)$.

Table S6. Geometrical parameters used to calculate bending strain $(\varepsilon)$. The mean value of the bending strain (shown in red) was determined on the basis of measurements of five different samples for the compound 6 . Thickness $(t)$ of the selected crystals was measured before bending, length $(L)$ and maximal displacement $\left(h_{\max }\right)$ were measured at the point of maximal curvature (see Figure S24 below).

\begin{tabular}{cccccc}
\hline \hline Sample & $\overline{\boldsymbol{t}} /$ & $\boldsymbol{L} /$ & $\boldsymbol{h}_{\max }$ & $\boldsymbol{R} / \mathbf{m m}$ & $\boldsymbol{\varepsilon} / \boldsymbol{\%}$ \\
\hline \hline $\mathbf{6 - 1}$ & 0.041 & 1.682 & 0.061 & 5.828 & $\mathbf{0 . 3 4 9}$ \\
$\mathbf{6 - 2}$ & 0.026 & 2.013 & 0.189 & 2.775 & $\mathbf{0 . 4 7 5}$ \\
$\mathbf{6 - 3}$ & 0.024 & 1.388 & 0.076 & 3.207 & $\mathbf{0 . 3 7 4}$ \\
$\mathbf{6 - 4}$ & 0.024 & 1.512 & 0.091 & 3.186 & $\mathbf{0 . 3 8 2}$ \\
$\mathbf{6 - 5}$ & 0.014 & 1.122 & 0.115 & 1.426 & $\mathbf{0 . 4 9 1}$ \\
\hline & & & & average & $\mathbf{0 . 4 1 4} \pm \mathbf{0 . 0 6 4}$ \\
\hline
\end{tabular}



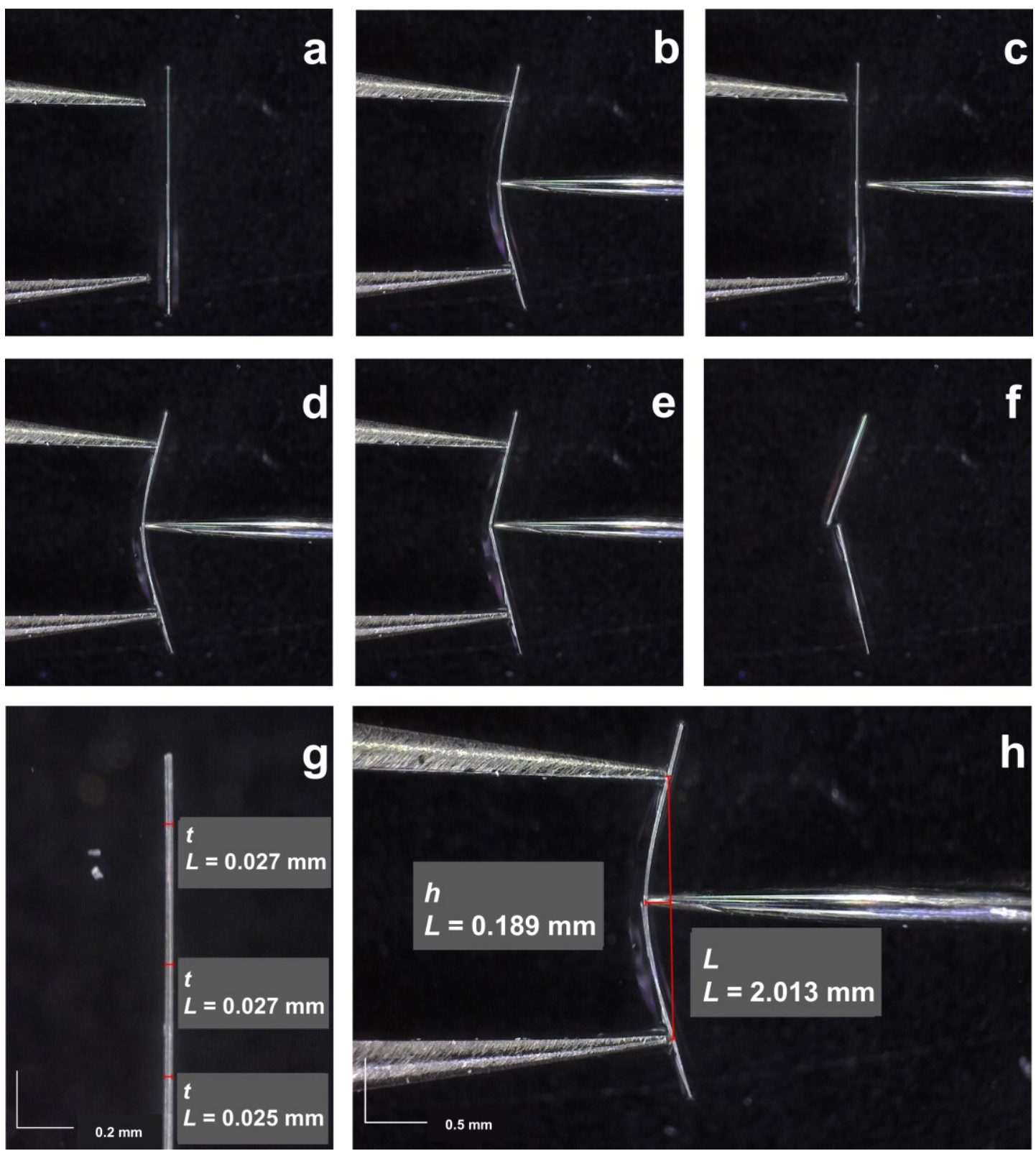

Figure S24. Bending experiment with $\left[\mathrm{Cdl}_{2}(3-\mathrm{Ipy})_{2}\right]_{n}$ (6, sample 6-2, images a-c and $\mathrm{h}$ magnified 70 times, image g magnified 200 times), $\varepsilon=0.48 \%$. Slight elastic bending of the crystal followed by relaxation $(a-c)$; crystal fractures once bent over the critical radius $(d-f)$. Geometrical parameters: (g) thickness $t$, (h) length $L$ and maximal displacement $h$. 


\section{Atomic force microscopy}

AFM topography and mechanical measurements were performed at a room temperature on a commercial MultiMode 8 AFM (Bruker). NCHV-A silicon probes (Bruker, resonance frequency 320 $\mathrm{kHz}$, spring constant $42 \mathrm{~N} \mathrm{~m}^{-1}$ ) were used to obtain the height images and to determine the mechanical properties of the straight and bent crystals 1-6. The deflection sensitivity of the cantilever was estimated from the slope of the loading curve obtained on sapphire sample and the spring constant was calibrated according to the Sader method. ${ }^{7}$ Reference measurements on a polystyrene standard sample (PSFILM-12M, Bruker, $E=2.70 \mathrm{GPa}, v=0.34$ ) were used to estimate the tip radius (the nominal tip radius is $8 \mathrm{~nm}$ and estimated tip radius values were in the range from $4 \mathrm{~nm}$ to $12 \mathrm{~nm}$ ).

Freshly prepared crystals were extracted form solution and glued (straight or bent) on the metal disks. Force-separation curves were acquired using NanoScope software v9.7 in the force volume mode, where the matrix of $32 \times 32$ force curves were obtained on the crystal surface. To ensure the reproducibility and the statistical significance of the results the measurements were conducted on a few different crystal samples of each compound (1-6). Data analyses were performed using NanoScope Analysis v2.0 (Bruker). Young's moduli of samples were estimated from fitting individual force-separation curves on Hertzian model ( $R^{2}$ were approx. 0.95)..$^{8}$ The Young's moduli of straight and bent crystals 1-6 shown in Table S7 are averaged values of Young's moduli acquired from fitting force-separation curves (at least 1500 datapoints were collected) for each compound.

Table S7. Young's moduli obtained on straight $(1-6)$ and plastically bent $(1-3,5)$ crystals.

\begin{tabular}{|c|c|c|c|c|}
\hline \multirow{2}{*}{ Compound } & & \multirow{2}{*}{$\begin{array}{l}\text { Indented } \\
\text { facet }\end{array}$} & \multicolumn{2}{|c|}{$E / G P a$} \\
\hline & & & straight & bent \\
\hline$\left[\mathrm{CdBr}_{2}(3-\mathrm{Clpy})_{2}\right]_{n}$ & (1) & (011) & $2.02 \pm 0.55$ & $0.86 \pm 0.27$ \\
\hline$\left[\mathrm{Cdl}_{2}(3-\mathrm{Clpy})_{2}\right]_{n}$ & (2) & (011) & $1.01 \pm 0.25$ & $0.47 \pm 0.11$ \\
\hline$\left[\mathrm{Cdl}_{2}(3-\mathrm{Brpy})_{2}\right]_{n}$ & (3) & (011) & $2.63 \pm 0.79$ & $0.93 \pm 0.25$ \\
\hline$\left[\mathrm{CdCl}_{2}(3-\mathrm{Ipy})_{2}\right]_{n}$ & (4) & (001) & $5.23 \pm 1.05$ & - \\
\hline$\left[\mathrm{CdBr}_{2}(3-\operatorname{lpy})_{2}\right]_{n}$ & (5) & (001) & $3.61 \pm 0.89$ & $2.11 \pm 0.45$ \\
\hline$\left[\mathrm{Cdl}_{2}(3-\mathrm{Ipy})_{2}\right]_{n}$ & (6) & (011) & $4.67 \pm 0.93$ & - \\
\hline
\end{tabular}




\section{Computational studies}

DFT study was performed in Gaussian $16^{9}$ with the M06-2X/DGDZVP method, which performs very well for the calculation of halogen-bond strengths among DFT methods with small basis sets. ${ }^{10}$ Each neighbouiring 1-D chain was represented by three octahedrally coordinated Cd(II) centres and a pairwise interaction energies between neighbouring 1-D polymeric chains were calculated and corrected by basis set superposition errors (BSSE) according to the counterpoise method of Boys and Bernardi. ${ }^{11,12}$ All the calculated values are divided by three to obtain the normalized interaction energies per one metal centre. Isostructural compounds 1-3 and $\mathbf{6}$ display only two types of pairwise interactions, type $\mathbf{A} \mathbf{1}\left[\mathrm{C}-\mathrm{X} \cdots \mathrm{X}^{\prime}(\mathrm{Cd})\right.$ halogen and $\mathrm{C}-\mathrm{H} \cdots \mathrm{X}^{\prime}(\mathrm{Cd})$ hydrogen

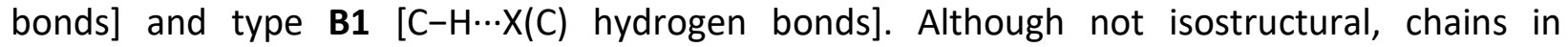
compounds $\mathbf{4}$ and $\mathbf{5}$ are similarly connected by type $\mathbf{A} 2$ [C-X $\cdots X^{\prime}(C d)$ halogen bonds], type $\mathbf{A} \mathbf{3}$ $\left[\mathrm{C}-\mathrm{H} \cdots \mathrm{X}^{\prime}(\mathrm{Cd})\right.$ hydrogen bonds] and type $\mathbf{B} 2[\mathrm{C}-\mathrm{H} \cdots \mathrm{X}(\mathrm{C})$ hydrogen bonds] interaction.

Rather than considering only two neighbouring molecules (each represented as a finite 1-D chain, Figure S25), interaction energies were also calculated for a system of four 1-D chains (Figure S26). Each system was split in two ways, either crossing (type $\mathbf{C 1}$ ) or connecting (type D1) antiparallel layers of polymeric chains extending in the $b$ direction (for isostructural compounds 1-3 and 6, green arrows in Figure S25). Interactions of type D1 connecting the antiparallel layers are much stronger than type $\mathbf{C 1}$ intersecting the layers. Both types of interactions are stronger for elastically flexible (6) in comparison with plastically bendable crystals (1-3 ). Lower symmetry of 4 and 5 (1-D chains arranged in parallel fashion exclusively) produces four possible arrangements between four molecules, two of them intersecting and two connecting the parallel-arranged layers of 1-D chains (green arrows in Figure S26). 

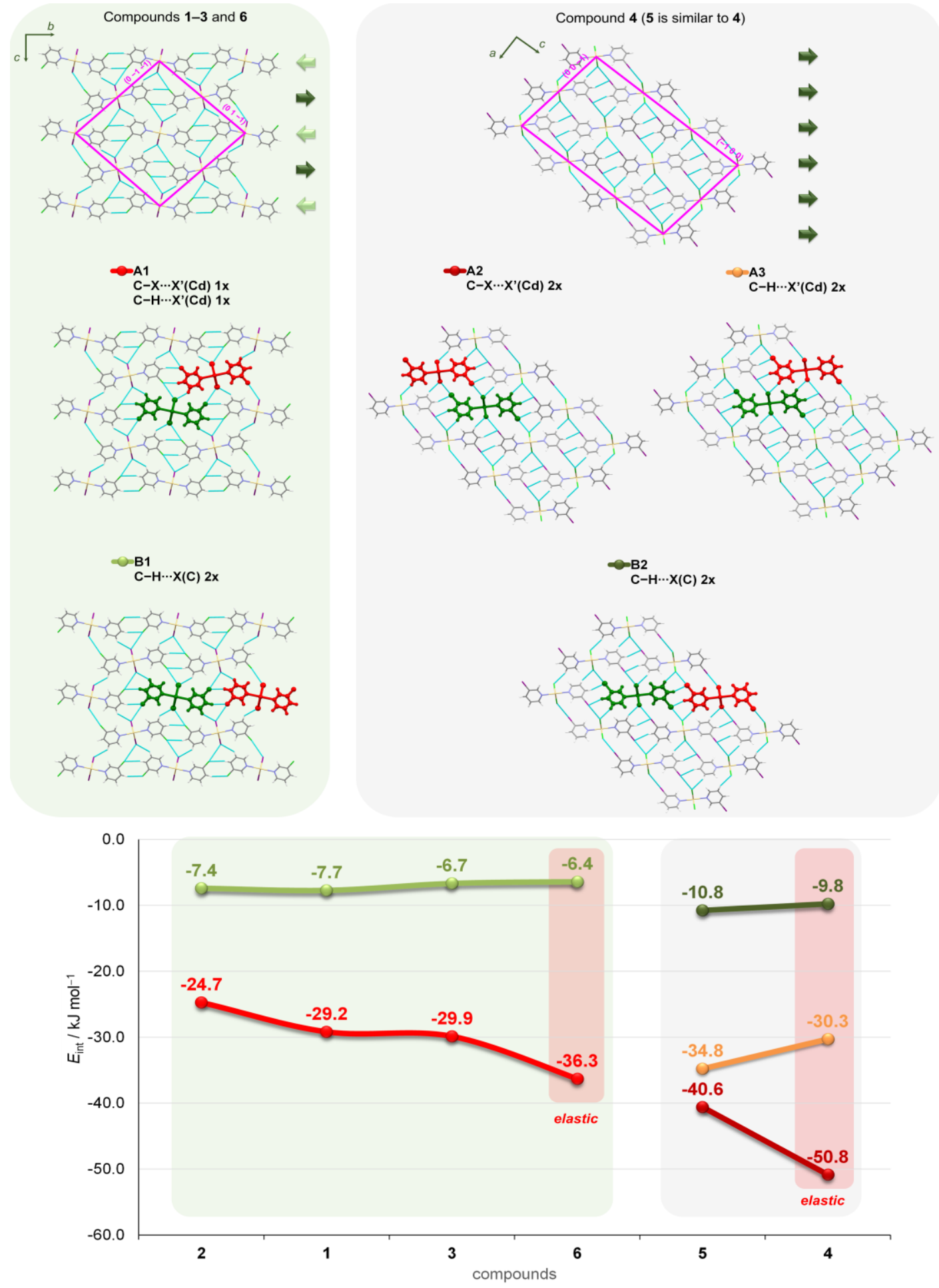

Figure S25. The M06-2X/DGDZVP interaction energies (corrected by BSSE) calculated for molecular pairs (between green and red fragments, each represented as a single 1-D polymeric chain) connected by different types of intermolecular interactions (A1-A3 and B1-B2) in the crystal structures of compounds 1-6. 

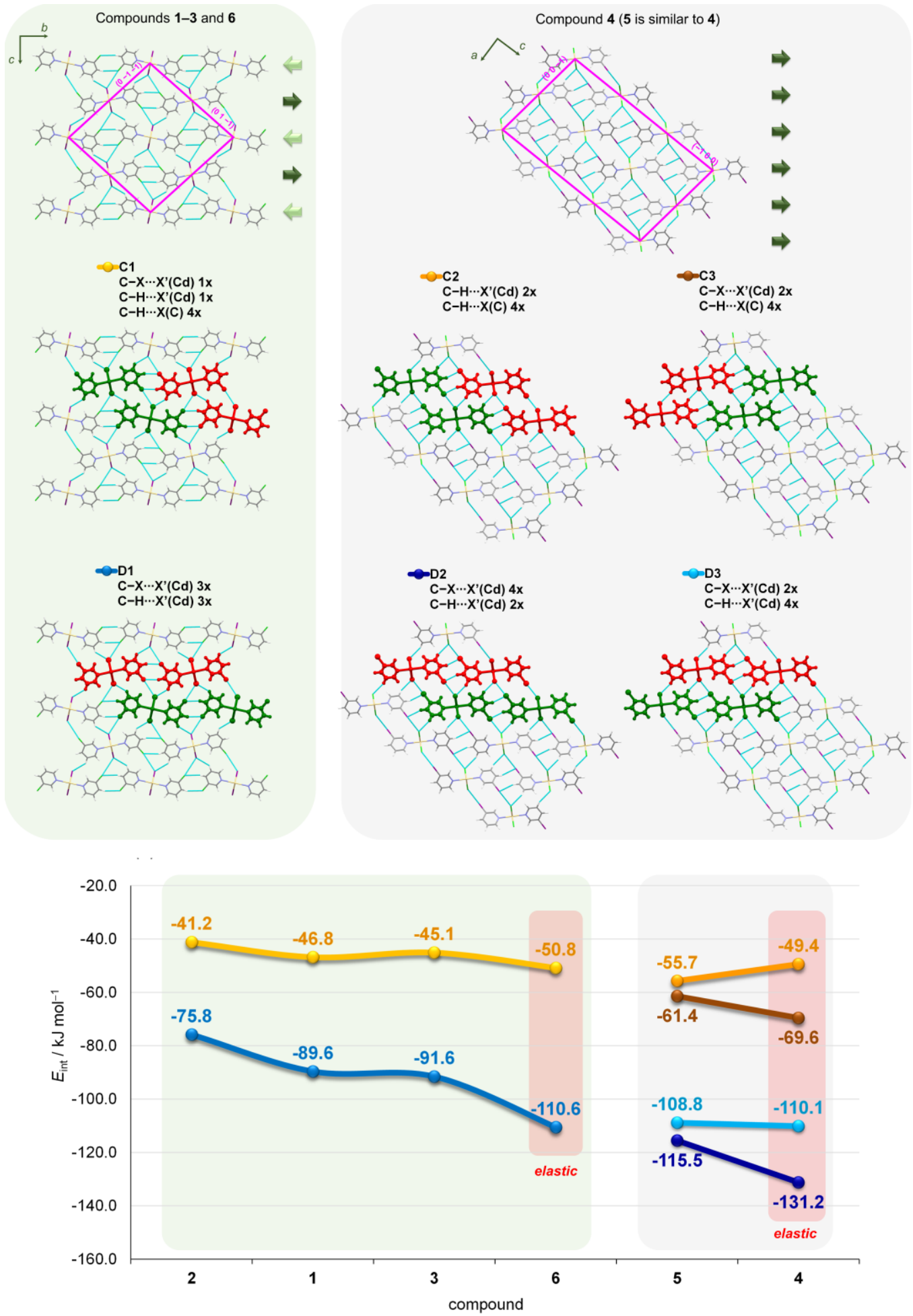

Figure S26. The M06-2X/DGDZVP interaction energies (corrected by BSSE) calculated for molecular pairs (between green and red fragments, each represented as two 1-D polymeric chains) connected by different types of intermolecular interactions (C1-C3 and D1-D3) in the crystal structures of compounds 1-6. 


\section{References}

1 CrysAlisPRO, Oxford Diffraction/Agilent Technologies UK Ltd, Yarnton, England.

2 Sheldrick, G. M. SHELXT- Integrated space-group and crystal-structure determination. Acta Crystallogr. 2015, A71, 3.

3 Sheldrick, G. M. Acta Crystallogr., 2008, A64, 112.

4 Macrae, C. F.; Bruno, I. J.; Chisholm, J. A.; Edgington, P. R.; McCabe, P.; Pidcock, E.; Rodriguez-Monge, L.; Taylor, R.; van de Streek, J.; Wood, P. A. Mercury CSD 2.0 - new features for the visualization and investigation of crystal structures. J. Appl. Crystallogr. 2008, 41, 466.

5 Lommerse, J. P. M.; Stone, A. J.; Taylor, R.; Allen, F. H. The Nature and Geometry of Intermolecular Interactions between Halogens and Oxygen or Nitrogen. J. Am. Chem. Soc., 1996, 118, 3108.

6 Timoshenko, S. Strength of materials, D. Van Nostrand Company, New York, 1940.

7 Sader, J. E.; Chon, J. W. M.; Mulvaney, P. Calibration of rectangular atomic force microscope cantilevers. Rev. Sci. Instrum., 1999, 70, 3967.

8 Hertz, H. J. Ueber die Berührung fester elasticher Körper. Reine Angew. Math., 1881, 92, 156.

9 Gaussian 16, Revision C.01, Frisch, M. J.; Trucks, G. W.; Schlegel, H. B.; Scuseria, G. E.; Robb, M. A.; Cheeseman, J. R.; Scalmani, G.; Barone, V.; Petersson, G. A.; Nakatsuji, H.; Li, X.; Caricato, M.; Marenich, A. V.; Bloino, J.; Janesko, B. G.; Gomperts, R.; Mennucci, B.; Hratchian, H. P.; Ortiz, J. V.A.; Izmaylov, F.; Sonnenberg, J. L.; Williams-Young, D.; Ding, F.; Lipparini, F.; Egidi, F.; Goings, J.; Peng, B.; Petrone, A.; Henderson, T.; Ranasinghe, D.; Zakrzewski, V. G.; Gao, J.; Rega, N.; Zheng, G.; Liang, W.; Hada, M.; Ehara, M.; Toyota, K.; Fukuda, R.; Hasegawa, J.; Ishida, M.; Nakajima, T.; Honda, Y.; Kitao, O.; Nakai, H.; Vreven, T.; Throssell, K.; Montgomery, J. A. Jr.; Peralta, J. E.; Ogliaro, F.; Bearpark, M. J.; Heyd, J. J.; Brothers, E. N.; Kudin, K. N.; Staroverov, V. N.; Keith, T. A.; Kobayashi, R.; Normand, J.; Raghavachari, K.; Rendell, A. P.; Burant, J. C.; Iyengar, S. S.; Tomasi, J.; Cossi, M.; Millam, J. M.; Klene, M.; Adamo, C.; Cammi, R.; Ochterski, J. W.; Martin, R. L.; Morokuma, K.; Farkas, O.; Foresman, J. B.; Fox, D. J. Gaussian, Inc., Wallingford CT, 2016.

10 Siiskonen, A.; Priimagi, A.; Benchmarking DFT methods with small basis sets for the calculation of halogen-bond strengths. J. Mol. Model. 2017, 23, 50.

11 Boys, S. F.; Bernardi, F. The calculation of small molecular interactions by the differences of separate total energies. Some procedures with reduced errors. Mol. Phys. 1970, 19, 553.

12 Simon, S.; Duran, M.; Dannenberg, J. J. How does basis set superposition error change the potential surfaces for hydrogenbonded dimers? J. Chem. Phys. 1996, 105, 11024. 